\title{
Utilization of protein in red clover and alfalfa silages by lactating dairy cows and growing lambs
}

\author{
Glen A. Broderick ${ }^{1,2}$ \\ Agricultural Research Service, USDA, US Dairy Forage Research Center, Madison, WI 53706, and \\ Department of Dairy Science, University of Wisconsin, Madison 53706
}

\begin{abstract}
Feeding trials were conducted with lactating cows and growing lambs to quantify effects of replacing dietary alfalfa silage (AS) with red clover silage (RCS) on nutrient utilization. The lactation trial had a $2 \times$ 4 arrangement of treatments: AS or RCS fed with no supplement, rumen-protected Met (RPM), rumenprotected Lys (RPL), or RPM plus RPL. Grass silage was fed at $13 \%$ of dry matter (DM) with AS to equalize dietary neutral detergent fiber (NDF) and crude protein contents. All diets contained (DM basis) 5\% corn silage and $16 \%$ crude protein. Thirty-two multiparous (4 ruminally cannulated) plus 16 primiparous Holstein cows were blocked by parity and days in milk and fed diets as total mixed rations in an incomplete $8 \times 8$ Latin square trial with four 28 -d periods. Production data (over the last $14 \mathrm{~d}$ of each period) and digestibility and excretion data (at the end of each period) were analyzed using the MIXED procedure of SAS (SAS Institute Inc., Cary, NC). Although DM intake was $1.2 \mathrm{~kg} / \mathrm{d}$ greater on AS than RCS, milk yield and body weight gain were not different. However, yields of fat and energy-corrected milk as well as milk content of fat, true protein, and solids-not-fat were greater on AS. Relative to AS, feeding RCS increased milk and energy-corrected milk yield per unit of DM intake, milk lactose content, and apparent $\mathrm{N}$ efficiency and reduced milk urea. Relative to AS, apparent digestibility of $\mathrm{DM}$, organic matter, NDF, and acid detergent fiber were greater on RCS, whereas apparent and estimated true $\mathrm{N}$ digestibility were lower. Urinary $\mathrm{N}$ excretion and ruminal concentrations of ammonia, total AA, and branched-chain volatile fatty acids were reduced on RCS, indicating reduced ruminal protein degradation. Supplementation of RPM increased intake, milk
\end{abstract}

\footnotetext{
Received August 15, 2017.

Accepted October 21, 2017.

${ }^{1}$ Corresponding author: gbroderi@wisc.edu

${ }^{2}$ Retired; present address: Broderick Nutrition and Research LLC, Madison, WI 53705.
}

true protein, and solids-not-fat content and tended to increase milk fat content. There were no silage $\times$ RPM interactions, suggesting that RPM was equally limiting on both AS and RCS. Supplementation of RPL did not influence any production trait; however, a significant silage $\times$ RPL interaction was detected for intake: RPL reduced intake of AS diets but increased intake of RCS diets. Duplicated metabolism trials were conducted with lambs confined to metabolism crates and fed only silage. After adaptation, collections of silage refusals and excreta were made during ad libitum feeding followed by feeding DM restricted to $2 \%$ of body weight. Intake of DM was not different when silages were fed ad libitum. Apparent digestibility of DM, organic matter, NDF, and hemicellulose was greater in lambs fed RCS on both ad libitum and restricted intake; however, acid detergent fiber digestibility was only greater at restricted intake. Apparent and estimated true $\mathrm{N}$ digestibility was substantially lower, and $\mathrm{N}$ retention was reduced, on RCS. Results confirmed greater DM and fiber digestibility in ruminants and $\mathrm{N}$ efficiency in cows fed RCS. Specific loss of Lys bioavailability on RCS was not observed. Based on milk composition, Met was the first-limiting AA on both silages; however, Met was not limiting based on production and nutrient efficiency. Depressed true $\mathrm{N}$ digestibility suggested impaired intestinal digestibility of rumen-undegraded protein from RCS.

Key words: milk production, alfalfa silage, red clover, silage, nitrogen utilization

\section{INTRODUCTION}

Forages such as alfalfa (Medicago sativa) are often harvested as silage rather than hay because greater mechanization and speed of harvest reduces risk of weather damage. However, during ensiling, typically more than half of the $\mathrm{CP}$ in alfalfa is broken down to small peptides and AA by enzymes released from cell rupture in the foliage (McDonald et al., 1991). Red clover (Trifolium pratense) has a polyphenol oxidase enzyme (PPO) system that forms o-quinones from en- 
dogenous plant $o$-diphenols; these $o$-quinones react with foliage proteins to substantially reduce their breakdown in both the silo (Lee et al., 2004) and the rumen (Brito et al., 2007). Lower yields, poorer persistency, and slower field drying rates of red clover have limited its widespread use in North America. We have conducted several lactation trials to determine the relative feeding value of alfalfa silage (AS) and red clover silage (RCS) for dairy cows. A summary from 5 trials showed similar yields of milk and protein, reduced MUN, and 3.5 percentage units greater $\mathrm{N}$ efficiency when lactating cows were fed RCS containing one-third less NPN than AS (Broderick, 2002); however, DMI and milk fat yield were higher on AS.

Lee et al. (2009) speculated that the PPO reaction mechanism might result in greater reduction in bioavailability of Met rather than Lys in the RUP in RCS. However, Prigent et al. (2008) observed that, among the essential AA, Lys residues were the most reactive to o-quinone formed from the o-diphenol chlorogenic acid. Relative responsiveness to feeding Met or Lys as rumen-protected AA in cows fed RCS versus AS may indicate which of these essential AA is most affected by the PPO action. Our hypothesis was that PPO activity in RCS would cause greater reduction of Lys rather than Met bioavailability but that increased RUP formation would improve $\mathrm{N}$ efficiency. Therefore, the objectives of these experiments were to assess, relative to AS, whether PPO action in RCS caused (1) greater reduction in bioavailability of Met or Lys and (2) a net improvement in $\mathrm{N}$ utilization.

\section{MATERIALS AND METHODS}

\section{Harvest and Composition of Legume Silages}

Alfalfa and red clover were both established in August 2009 at the US Dairy Forage Center farm (Prairie Du Sac, WI) on fields fertilized with $\mathrm{P}$ and $\mathrm{K}$ according to soil test. Alfalfa silage was harvested from the second cutting on June 25, 2010, using a conventional mower conditioner; wilted for 1 to $2 \mathrm{~d}$ to about $40 \% \mathrm{DM}$; chopped to a theoretical length of $2.9 \mathrm{~cm}$; and ensiled without additives in a plastic bag (Ag-Bag Systems, St. Nazianz, WI). Red clover silage (cultivar $=$ Arlington) was harvested using the same equipment from the first cutting on May 28 and 29, 2010, and, to obtain additional forage DM, from the second cutting on June 30, 2010; wilted for $2 \mathrm{~d}$ to about $40 \% \mathrm{DM}$; and ensiled in separate plastic bags (Ag-Bag Systems) for each cutting. Approximately twice as much RCS was harvested on May 28 to 29 as on June 30, 2010. No forage was rained on during any harvest. Samples of forage were collected from every load, dried for $48 \mathrm{~h}$ at $60^{\circ} \mathrm{C}$, and then analyzed for $\mathrm{DM}$ at $105^{\circ} \mathrm{C}$, total $\mathrm{N}$ by combustion (Leco 2000; Leco Instruments Inc., St. Joseph, MI), and NDF using heat stable $\alpha$-amylase (Van Soest et al., 1991) and $\mathrm{Na}_{2} \mathrm{SO}_{3}$ (Hintz et al., 1996). Crude protein (total $\mathrm{N} \times 6.25$ ) and $\mathrm{NDF}$ were computed on the basis of $105^{\circ} \mathrm{C}$ DM. Mean (SD) composition before ensiling of alfalfa was $43.0 \%$ (5.5) DM, $21.8 \%$ (1.2) CP, and $39.3 \%$ (1.4) NDF. Mean compositions before ensiling of red clover were $40.7 \%$ (3.2) DM, $17.0 \%$ (1.6) CP, and $39.3 \%$ (2.0) NDF for the first cutting and $42.0 \%$ (2.0) DM, $18.1 \%$ (1.9) CP, and 40.0\% (1.7) NDF for the second cutting. Prior to silo opening before the lactation trial, AS had been ensiled for $62 \mathrm{~d}$ and RCS had been ensiled for $90 \mathrm{~d}$ (first cutting) and $57 \mathrm{~d}$ (second cutting). At the end of the lactation study, 8 compressed and wrapped rectangular bales (2 from AS, 4 from the first cutting of RCS, and 2 from the second cutting of RCS) containing 592 to $810 \mathrm{~kg}$ of as-fed silage were made using the compacting machine described by Digman et al. (2010). These baled silages were stored under cover from December 2010 to April 2011 and then fed in the lamb $\mathrm{N}$ metabolism trials described below.

\section{Lactation Trial}

Thirty-two multiparous Holstein cows [4 of which were fitted with permanent $10-\mathrm{cm}$ ruminal cannulas (Bar Diamond Inc., Parma, ID); mean (SD) 2.4 (0.7) parity, 111 (35.4) DIM, 50 (4.9) kg of milk/d, and 582 (55) $\mathrm{kg}$ of BW] plus 16 primiparous cows [mean (SD) 126 (29.7) DIM, 46 (2.0) $\mathrm{kg}$ of milk/d, and 512 (34) kg of BW] were used in the trial. Cows were distributed by DIM and parity to 3 pairs of 2 blocks each (2 pairs of blocks of multiparous cows and 1 pair of blocks of primiparous cows) and randomly assigned to the 2 sets of 8 treatment sequences (design "18", Table 4 in Davis and Hall, 1969). All cows were injected every other week with bST (500 mg of Posilac; Elanco Animal Health, Greenfield, IN) beginning around 60 DIM; injections were synchronized such that animals received a full dose on d 1 followed by subsequent bST doses at 14-d intervals throughout the trial. Cows were housed in tiestalls and had free access to water. The Animal Care and Use Committee of the College of Agricultural and Life Sciences of the University of Wisconsin-Madison approved all procedures involving the animals.

Diets were fed as TMR and contained either AS plus grass silage (4 diets) or RCS (4 diets), corn silage, rolled high-moisture corn, dried finely ground shelled corn, solvent-extracted soybean meal, and a mineralvitamin supplement. The RCS from cuttings 1 and 2 was mixed into the TMR in DM ratios of 2:1. The grass silage was made from a mixture largely of bluegrass, bromegrass, and orchardgrass, with a small amount of 
reed canarygrass, and was harvested at first cutting on June 1, 2010, on the US Dairy Forage Research farm using the methodology applied to the AS and RCS. Three premixes were prepared containing ground shelled corn plus liquid molasses only (control); ground shelled corn, liquid molasses, and rumen-protected Met (RPM; Smartamine-M, Adisseo Corp., Alpharetta, GA); and ground shelled corn, liquid molasses, and rumen-protected Lys (RPL; AminoShure-L, Balchem Corp., New Hampton, NY). These were added to the TMR to give 8 diets: (1) AS plus control, (2) AS plus RPM, (3) AS plus RPL, (4) AS plus RPM and RPL, (5) RCS plus control, (6) RCS plus RPM, (7) RCS plus RPL, and (8) RCS plus RPM and RPL. At the overall mean DMI observed during the trial, RPM and RPL supplements provided, respectively, $11 \mathrm{~g} / \mathrm{d}$ of chemical DL-Met and $27 \mathrm{~g} / \mathrm{d}$ of chemical L-Lys. Assuming 80\% bioavailability of Met in the RPM (Zhou et al., 2016) and $64 \%$ bioavailability of Lys in the RPL (Lee et al., 2012), this corresponded to $9 \mathrm{~g} / \mathrm{d}$ of absorbed Met and $17 \mathrm{~g} / \mathrm{d}$ of absorbed Lys.

Each of the 4 experimental periods lasted $28 \mathrm{~d}$ and consisted of $14 \mathrm{~d}$ for adaptation after diet switching and $14 \mathrm{~d}$ for collection of intake and production data. Diets were offered once daily at $1000 \mathrm{~h}$; orts were collected and weights were recorded at $0900 \mathrm{~h}$. Feeding rate was adjusted daily to yield orts equivalent to about 5 to $10 \%$ of intake. Weekly composites of AS, RCS, grass silage, corn silage, high-moisture shelled corn, and the 8 different TMR and orts were obtained from daily subsamples of about $0.5 \mathrm{~kg}$ of each material that were stored at $-20^{\circ} \mathrm{C}$. Weekly samples also were collected of the dry ingredients (ground shelled corn, soybean meal, and the 3 premixes) and stored at room temperature. Dry matter was determined on these weekly composites by drying at $60^{\circ} \mathrm{C}$ for $48 \mathrm{~h}$ and on weekly dry ingredients by drying for $24 \mathrm{~h}$ at $105^{\circ} \mathrm{C}$ (method 967.03; AOAC, 1990). Weekly DM contents were used to adjust DM composition of TMR every week over the course of the trial. Intake of DM was computed from $60^{\circ} \mathrm{C} \mathrm{DM}$ determinations of weekly composites of TMR and orts.

Weekly composite samples of AS and RCS also were stored at $-20^{\circ} \mathrm{C}$. Composites were thawed, water extracts were prepared (Muck, 1987), and extract $\mathrm{pH}$ was measured. Extracts were deproteinized (Muck, 1987) and then analyzed for NPN (Muck, 1987) using a combustion assay (Leco 2000) and, using flowinjection assays (Lachat Quik-Chem 8000 FIA; Lachat Instruments, Loveland, CO), for ammonia by a phenolhypochlorite method (Lachat method 18-107-06-1-A) and total AA by a fluorimetric reaction with o-phthaldialdehyde (Roth, 1971). Leucine was the standard in the o-phthaldialdehyde assay, and total AA values are reported in Leu equivalents.
Dried $\left(60^{\circ} \mathrm{C}\right)$ samples of AS, RCS, grass silage, corn silage, and high-moisture shelled corn and undried samples of ground shelled corn, soybean meal, and the 3 premixes from wk 3 and 4 of each period (8 samples of each ingredient over the trial) were ground to pass a 1-mm screen (Wiley mill; Arthur H. Thomas, Philadelphia, PA). These were analyzed for total N, DM (method 967.03; AOAC, 1990), ash, and OM (AOAC, 1980); sequentially for NDF, ADF, and ADIN using heat-stable $\alpha$-amylase and $\mathrm{Na}_{2} \mathrm{SO}_{3}$ (Van Soest et al., 1991; Hintz et al., 1996); and for NDIN omitting $\alpha$-amylase and $\mathrm{Na}_{2} \mathrm{SO}_{3}$ during extraction (Licitra et al., 1996). The TMR samples collected during wk 4 of each period were also were analyzed for indigestible ADF (ADF remaining after $288 \mathrm{~h}$ of in situ incubation) by the method of Huhtanen et al. (1994). Mean composition data for the silages fed in the lactation and lamb trials are given in Table 1. Composition of the experimental diets actually fed during the lactation trial (based on daily mean weights of as-fed ingredients and weekly mean DM contents of each ingredient) is described in Table 2.

Cows were milked twice daily at 0500 and $1700 \mathrm{~h}$, and milk yield was recorded at each milking in all experimental periods. Milk samples from a.m. and p.m. milkings were collected on d 17 to 18 and 24 to 25 of each period and analyzed for fat, true protein, lactose, SNF, and MUN by infrared analysis (AgSource, Verona, WI) with a Foss FT6000 (Foss North America Inc., Eden Prairie, MN) using AOAC International (1997) method 972.16. Concentrations and yields of fat, true protein, lactose, and SNF as well as MUN concentration were computed as weighted means based on a.m. and p.m. milk yields on each test day. Yields of ECM (Krause and Combs, 2003) also were computed. Efficiency of conversion of feed DM was calculated for each cow over the last 2 wk of each period by dividing mean yield of actual milk, and of ECM, by mean DMI. Apparent $\mathrm{N}$ efficiency (assuming no retention or mobilization of body $\mathrm{N}$ ) also was computed for each cow by dividing the period mean for milk $\mathrm{N}$ secretion (milk true protein/6.38) by mean $\mathrm{N}$ intake. For computation of $\mathrm{BW}$ change, BW was measured on 3 consecutive days at the beginning of the experiment and at the end of each period.

Spot urine and fecal samples were collected on $\mathrm{d}$ 28 of each period at $6 \mathrm{~h}$ before and $6 \mathrm{~h}$ after feeding. Urine was immediately diluted by mixing $15 \mathrm{~mL}$ of each sample with $60 \mathrm{~mL}$ of $0.072 \mathrm{~N} \mathrm{H}_{2} \mathrm{SO}_{4}$ and storing at $-20^{\circ} \mathrm{C}$ until analysis. Fecal samples were dried for $72 \mathrm{~h}$ at $60^{\circ} \mathrm{C}$, ground through a 1-mm screen (Wiley mill), and composited on an equal DM basis to obtain 1 fecal sample/cow per period. All fecal samples were analyzed for DM, ash, OM, NDF, ADF, total N, and 
indigestible ADF using the assays described above. Indigestible ADF was used as an internal marker to estimate apparent nutrient digestibility and fecal output based on computations used by Cochran et al. (1986). True $\mathrm{N}$ digestibility was estimated assuming metabolic fecal $\mathrm{N}=4.8 \mathrm{~g}$ of $\mathrm{N}(30 \mathrm{~g}$ of $\mathrm{CP}) / \mathrm{kg}$ of DMI per day (NRC, 2001). Urine samples were thawed and analyzed for total N by elemental analysis (Leco FP-2000), for urea using an automated colorimetric assay (Broderick and Clayton, 1997), and creatinine (Valadares et al., 1999) adapted to flow injection (Lachat Quik-Chem 8000 FIA). Daily urine volume and excretion of urea N and total $\mathrm{N}$ were estimated from mean urinary concentrations in each period assuming a creatinine excretion rate of $29 \mathrm{mg} / \mathrm{kg}$ of BW (Valadares et al., 1999).

On d 27 to 28 of each period, about 100 to $200 \mathrm{~mL}$ of fluid digesta was collected from 4 locations in the ventral rumen at 0 (just before feeding), 1, 2, 4, 6, 8, 12,18 , and $24 \mathrm{~h}$ after feeding from the 4 lactating Holstein cows fitted with ruminal cannulas using the probe described by Colmenero and Broderick (2006). At each sampling, mixed fluid digesta was strained through 2 layers of cheesecloth, and $\mathrm{pH}$ was measured immediately in strained fluid using a glass electrode. Two 10-mL aliquots of ruminal fluid were then preserved in scintillation vials by addition of $0.2 \mathrm{~mL}$ of $50 \% \mathrm{H}_{2} \mathrm{SO}_{4}$ and stored at $-20^{\circ} \mathrm{C}$. The remaining fluid and digesta were returned to the rumen. Just before analysis, samples were thawed and centrifuged $(15,300 \times g$ for $20 \mathrm{~min}$ at $4^{\circ} \mathrm{C}$ ) and analyzed for ammonia and total AA using the assays described for AS and RCS extracts. Samples also were thawed and centrifuged $(28,000 \times g$ for $30 \mathrm{~min}$ at $4^{\circ} \mathrm{C}$ ), and individual and total VFA were determined by GLC (Broderick et al., 2015). This method does not resolve isovalerate and 2-methyl butyrate.

\section{Lamb Digestion and Metabolism Trials}

Duplicate digestion trials were conducted using growing lambs to quantify digestibility of DM, OM, N, $\mathrm{NDF}, \mathrm{ADF}$, and hemicellulose (NDF - ADF) and N metabolism when fed only the AS or RCS previously fed in the lactation study. The methodology applied in these studies was detailed by Jung et al. (2011) except that total daily urine output was collected into $\mathrm{H}_{2} \mathrm{SO}_{4}$. Briefly, each trial used 16 crossbred wether lambs with mean (SD) initial BW of 29 (2.2) $\mathrm{kg}$ (trial 1) and 33 (1.8) $\mathrm{kg}$ (trial 2). In each trial, treatments consisted of 1 compressed rectangular bale of AS or 1 of the 3 compressed rectangular bales of RCS that were fed as the sole feed. Each treatment was randomly assigned to 4 lambs that were confined to metabolism crates and had free access to water and a trace mineral block throughout both trials. Lambs were housed in an environmentally controlled room at the University of Wisconsin-Madison. A standard alfalfa hay was fed ad libitum for $5 \mathrm{~d}$, and then experimental silage treatments were fed ad libitum for a 12-d adaptation period followed by a 5 -d ad libitum phase for collection of feed refusals, feces, and urine. During ad libitum feeding, silage was offered to achieve a $10 \%$ refusal rate. Immediately after the ad libitum phase, offered DM was restricted to $2 \%$ of $\mathrm{BW}$. After a 5 -d adaptation to restricted feeding, feed refusals, feces, and urine were collected for $5 \mathrm{~d}$. During each 5 -d collection, weights of silage offered, refusals, and feces and urine excreted by each lamb were recorded. Pooled daily samples of each silage and refusals pooled for each lamb were obtained for every collection period and stored $\left(-20^{\circ} \mathrm{C}\right)$. Daily subsamples of $100 \mathrm{~g}$ of feces and of urine from each lamb were also stored at $\left(-20^{\circ} \mathrm{C}\right)$. A composite fecal

Table 1. Composition of dietary forage ingredients

\begin{tabular}{|c|c|c|c|c|c|c|c|c|}
\hline \multirow[b]{2}{*}{ Component } & \multicolumn{2}{|c|}{ Alfalfa silage } & \multicolumn{2}{|c|}{ Red clover silage } & \multicolumn{2}{|c|}{ Grass silage } & \multicolumn{2}{|c|}{ Corn silage } \\
\hline & Mean & SEM & Mean & SEM & Mean & SEM & Mean & SEM \\
\hline DM, \% & 42.8 & 1.20 & 38.9 & 2.42 & 32.8 & 1.46 & 37.7 & 0.75 \\
\hline $\mathrm{CP}, \%$ of $\mathrm{DM}$ & 20.9 & 0.25 & 17.8 & 0.29 & 11.8 & 0.19 & 6.7 & 0.08 \\
\hline Ash, \% of DM & 10.8 & 0.22 & 12.4 & 0.17 & 8.7 & 0.08 & 4.3 & 0.13 \\
\hline $\mathrm{NDF}, \%$ of DM & 39.9 & 0.75 & 38.5 & 0.52 & 57.0 & 0.53 & 42.6 & 1.31 \\
\hline $\mathrm{ADF}, \%$ of $\mathrm{DM}$ & 29.9 & 0.61 & 24.6 & 0.33 & 34.5 & 0.32 & 26.6 & 0.82 \\
\hline Hemicellulose, ${ }^{1} \%$ of DM & 10.0 & - & 13.9 & - & 22.5 & - & 16.0 & - \\
\hline NDIN, \% of total N & 7.9 & 0.26 & 25.5 & 1.83 & - & - & - & - \\
\hline ADIN, $\%$ of total $\mathrm{N}$ & 3.4 & 0.11 & 6.0 & 0.43 & - & - & - & - \\
\hline $\mathrm{B} 2,{ }^{2} \%$ of total $\mathrm{N}$ & 4.6 & - & 19.6 & - & - & - & - & - \\
\hline NPN, \% of total N & 51.6 & 1.95 & 35.0 & 2.23 & - & - & - & - \\
\hline Ammonia, $\%$ of total $\mathrm{N}$ & 6.0 & 1.00 & 4.7 & 0.42 & - & - & - & - \\
\hline Total AA-N, ${ }^{3} \%$ of total $\mathrm{N}$ & 28.8 & 1.41 & 15.7 & 0.92 & - & - & - & - \\
\hline $\mathrm{pH}$ & 4.63 & 0.054 & 4.59 & 0.126 & - & - & - & - \\
\hline
\end{tabular}


sample, proportional to daily output, was prepared for each lamb; pooled silage, refusals, and fecal composites were dried $\left(48 \mathrm{~h}\right.$ at $\left.60^{\circ} \mathrm{C}\right)$ and later analyzed for $\mathrm{DM}$, ash, OM, NDF, and total N as described. Daily individual urine samples were analyzed for total $\mathrm{N}$ only. After completion of both ad libitum and restricted phases of the trial, the 16 lambs were rerandomized and reassigned to treatments, the design described was applied in the second experimental replicate, and lambs were fed silage from the other 4 bales. The face of each silage bale was sprayed daily with a $10 \%$ (vol/vol) solution of propionic acid during feed-out to restrict mold growth.

\section{Statistical Analysis}

Results were analyzed using the MIXED procedure of SAS (SAS Institute, 2013); significance was declared at $P \leq 0.05$, and trends were declared at $0.05<P$ $\leq 0.10$. The basic design of the lactation trial was an incomplete $8 \times 8$ Latin square replicated 6 times. The

Table 2. Diet $^{1}$ composition (\% of DM unless otherwise stated)

\begin{tabular}{|c|c|c|c|c|c|c|c|c|}
\hline \multirow[b]{2}{*}{ Item } & \multicolumn{4}{|c|}{ Alfalfa silage } & \multicolumn{4}{|c|}{ Red clover silage } \\
\hline & Control & Met & Lys & Met + Lys & Control & Met & Lys & Met + Lys \\
\hline \multicolumn{9}{|l|}{ Ingredient } \\
\hline Alfalfa silage & 47.4 & 47.4 & 47.4 & 47.4 & 0.0 & 0.0 & 0.0 & 0.0 \\
\hline Red clover silage & 0.0 & 0.0 & 0.0 & 0.0 & 59.8 & 59.8 & 59.8 & 59.8 \\
\hline Grass silage & 12.9 & 12.9 & 12.9 & 12.9 & 0.0 & 0.0 & 0.0 & 0.0 \\
\hline Corn silage & 5.2 & 5.2 & 5.2 & 5.2 & 5.2 & 5.2 & 5.2 & 5.2 \\
\hline Total forage & 65.4 & 65.4 & 65.4 & 65.4 & 65.0 & 65.0 & 65.0 & 65.0 \\
\hline High-moisture shelled corn & 18.4 & 18.4 & 18.4 & 18.4 & 18.5 & 18.6 & 18.6 & 18.5 \\
\hline Ground shelled corn & 9.8 & 9.8 & 9.5 & 9.4 & 9.1 & 8.9 & 8.7 & 8.7 \\
\hline Solvent soybean meal & 4.0 & 3.9 & 4.0 & 4.0 & 5.0 & 5.0 & 5.0 & 5.0 \\
\hline Molasses & 0.03 & 0.03 & 0.03 & 0.03 & 0.03 & 0.03 & 0.03 & 0.03 \\
\hline Smartamine- $\mathrm{M}^{2}$ & 0.00 & 0.06 & 0.00 & 0.06 & 0.00 & 0.06 & 0.00 & 0.06 \\
\hline AminoShure- $\mathrm{L}^{3}$ & 0.00 & 0.00 & 0.30 & 0.30 & 0.00 & 0.00 & 0.30 & 0.30 \\
\hline Calcium sulfate & 1.36 & 1.36 & 1.36 & 1.36 & 1.36 & 1.36 & 1.36 & 1.36 \\
\hline Biophos & 0.22 & 0.22 & 0.22 & 0.22 & 0.22 & 0.22 & 0.22 & 0.22 \\
\hline Sodium chloride & 0.18 & 0.18 & 0.18 & 0.18 & 0.18 & 0.18 & 0.18 & 0.18 \\
\hline Magnesium oxide/sulfate & 0.50 & 0.50 & 0.50 & 0.50 & 0.50 & 0.50 & 0.50 & 0.50 \\
\hline Vitamins and trace minerals ${ }^{4}$ & 0.13 & 0.13 & 0.13 & 0.13 & 0.13 & 0.13 & 0.13 & 0.13 \\
\hline \multicolumn{9}{|l|}{ Composition } \\
\hline $\mathrm{CP}$ & 16.0 & 15.9 & 15.9 & 15.9 & 15.6 & 15.6 & 15.6 & 15.6 \\
\hline Alfalfa silage CP, $\%$ of total CP & 62 & 62 & 62 & 62 & 0 & 0 & 0 & 0 \\
\hline Red clover silage $\mathrm{CP}, \%$ of total $\mathrm{CP}$ & 0 & 0 & 0 & 0 & 68 & 68 & 68 & 68 \\
\hline Ash & 7.1 & 7.1 & 7.1 & 7.1 & 8.4 & 8.4 & 8.4 & 8.4 \\
\hline NDF & 30.8 & 30.7 & 30.7 & 30.7 & 28.6 & 28.6 & 28.5 & 28.5 \\
\hline $\mathrm{ADF}$ & 20.9 & 20.9 & 20.9 & 20.9 & 17.7 & 17.7 & 17.7 & 17.7 \\
\hline Hemicellulose & 9.8 & 9.8 & 9.8 & 9.8 & 10.8 & 10.8 & 10.8 & 10.8 \\
\hline Ether extract ${ }^{5}$ & 3.0 & 3.0 & 3.0 & 3.0 & 2.9 & 2.9 & 2.9 & 2.9 \\
\hline $\mathrm{NFC}^{6}$ & 45.0 & 45.0 & 45.1 & 45.1 & 47.7 & 47.7 & 47.8 & 47.8 \\
\hline NDIN, $\%$ of total $\mathrm{N}$ & 10.1 & 10.1 & 10.1 & 10.1 & 19.1 & 19.1 & 19.1 & 19.1 \\
\hline ADIN, $\%$ of total $\mathrm{N}$ & 3.9 & 3.9 & 3.9 & 3.9 & 5.0 & 5.0 & 5.0 & 5.0 \\
\hline $\mathrm{B} 2, \%$ of total $\mathrm{N}$ & 6.2 & 6.2 & 6.2 & 6.2 & 14.1 & 14.1 & 14.1 & 14.1 \\
\hline $\mathrm{NE}_{\mathrm{L}}{ }^{7} \mathrm{Mcal} / \mathrm{kg}$ of DM & 1.52 & 1.52 & 1.52 & 1.52 & 1.52 & 1.52 & 1.52 & 1.52 \\
\hline $\mathrm{MP},{ }^{7} \mathrm{~g} / \mathrm{d}$ & 1,999 & 1,999 & 1,999 & 1,999 & 1,900 & 1,900 & 1,900 & 1,900 \\
\hline $\mathrm{NE}_{\mathrm{L}}$-allowable milk, ${ }^{7} \mathrm{~kg} / \mathrm{d}$ & 36.0 & 36.0 & 36.0 & 36.0 & 33.3 & 33.3 & 33.3 & 33.3 \\
\hline MP-allowable milk, ${ }^{7} \mathrm{~kg} / \mathrm{d}$ & 24.0 & 24.0 & 24.0 & 24.0 & 22.8 & 22.8 & 22.8 & 22.8 \\
\hline Lys:Met ratio in $\mathrm{MP}^{7}$ & 3.6 & 2.9 & 4.1 & 3.3 & 3.7 & 2.8 & 4.2 & 3.2 \\
\hline
\end{tabular}

${ }^{1}$ Control = no rumen-protected Met or rumen-protected Lys supplement; Met = supplementation with rumen-protected Met; Lys = supplementation with rumen-protected Lys; Met + Lys = supplementation with rumen-protected Met and rumen-protected Lys.

${ }^{2}$ Rumen-protected Met product from Adisseo Co. (Alpharetta, GA).

${ }^{3}$ Rumen-protected Lys product from Balchem Corp. (New Hampton, NY).

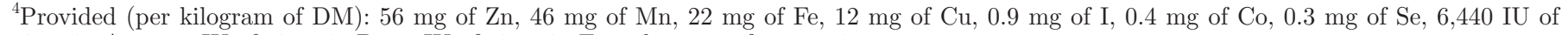
vitamin A, 2,000 IU of vitamin D, 16 IU of vitamin E, and $12 \mathrm{mg}$ of monensin.

${ }^{5}$ Computed using feed ether extract concentrations from NRC (2001) tables.

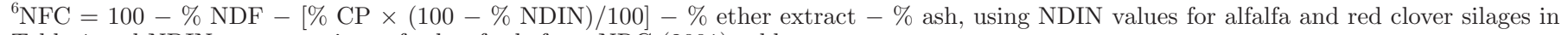
Table 1 and NDIN concentrations of other feeds from NRC (2001) tables.

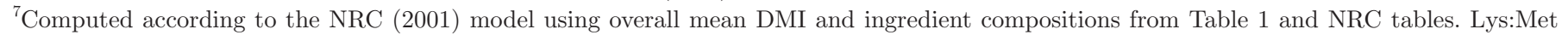
ratios were estimated assuming $80 \%$ bioavailability of Met and $64 \%$ bioavailability of Lys in rumen-protected AA supplements. 
following model was used to evaluate production and $\mathrm{N}$ excretion data from the lactation trial:

$$
\begin{aligned}
& \mathrm{Y}_{\mathrm{ijklmn}}=\mu+\mathrm{S}_{\mathrm{i}}+\mathrm{P}_{\mathrm{j}}+\mathrm{F}_{\mathrm{k}}+\mathrm{L}_{\mathrm{l}}+\mathrm{M}_{\mathrm{m}}+\mathrm{F} \times \mathrm{L}_{\mathrm{kl}}+\mathrm{F} \\
& \times \mathrm{M}_{\mathrm{km}}+\mathrm{L} \times \mathrm{M}_{\mathrm{lm}}+\mathrm{F} \times \mathrm{L} \times \mathrm{M}_{\mathrm{klm}}+\mathrm{C}_{\mathrm{n}}\left(\mathrm{S}_{\mathrm{i}}\right)+\mathrm{E}_{\mathrm{ijklmn}},
\end{aligned}
$$

where $Y_{\mathrm{ijk} k m n}=$ dependent variable; $\mu=$ overall mean; $\mathrm{S}_{\mathrm{i}}=$ effect of square $\mathrm{i}(\mathrm{i}=1$ to 6$) ; \mathrm{P}_{\mathrm{j}}=$ effect of period $\mathrm{j}(\mathrm{j}=1$ to 4$) ; \mathrm{F}_{\mathrm{k}}=$ effect of forage $\mathrm{k}(\mathrm{k}=1$ to 2 , AS or RCS); $\mathrm{L}_{1}=$ effect of RPL $(1=0$ or 1$) ; \mathrm{M}_{\mathrm{m}}=$ effect of $\mathrm{RPM}(\mathrm{m}=0$ or 1$) ; \mathrm{F} \times \mathrm{L}_{\mathrm{kl}}=$ interaction of forage and $\mathrm{RPL} ; \mathrm{F} \times \mathrm{M}_{\mathrm{km}}=$ interaction of forage and RPM; $\mathrm{L} \times$ $\mathrm{M}_{\mathrm{lm}}=$ interaction of RPL and RPM; F $\times \mathrm{L} \times \mathrm{M}_{\mathrm{klm}}=$ interaction of forage, RPL, and RPM; $\mathrm{C}_{n}\left(\mathrm{~S}_{\mathrm{i}}\right)=$ effect of cow $\mathrm{n}$ within square $\mathrm{i}$; and $\mathrm{E}_{\mathrm{ijklmn}}=$ residual error. All terms were considered fixed except for $\mathrm{C}_{\mathrm{n}}\left(\mathrm{S}_{\mathrm{i}}\right)$ and $\mathrm{E}_{\mathrm{ijklmn}}$, which were considered random. Least squares means and standard error of the mean from the overall analysis are given in Table 3. No 3-way interaction was significant $(P \geq 0.13)$, and none is reported.
Although it was assumed that RPM and RPL supplementation had no effect on ruminal traits, this assumption was tested using the following model:

$$
\mathrm{Y}_{\mathrm{ijk}}=\mu+\mathrm{L}_{\mathrm{i}}+\mathrm{M}_{\mathrm{j}}+\mathrm{Lv} \times \mathrm{M}_{\mathrm{ij}}+\mathrm{C}_{\mathrm{k}}+\mathrm{E}_{\mathrm{ijk}},
$$

where $Y_{\mathrm{ijk}}=$ dependent variable, $\mu=$ overall mean, $\mathrm{L}_{\mathrm{i}}$ $=$ effect of RPL (i $=0$ or 1$), M_{j}=$ effect of RPM $(j=$ 0 or 1$), \mathrm{L} \times \mathrm{M}_{\mathrm{ij}}=$ interaction of RPL and RPM, $\mathrm{C}_{\mathrm{k}}=$ effect of cow $\mathrm{k}(\mathrm{k}=1$ to 4$)$, and $\mathrm{E}_{\mathrm{ijk}}=$ residual error. All terms were considered fixed except for $\mathrm{C}_{\mathrm{k}}$ and $\mathrm{E}_{\mathrm{ijk}}$, which were considered random. This analysis detected only a trend for an effect of RPM on ruminal total AA $(P=0.06)$; probabilities for effects of RPM on all other ruminal traits were not significant $(P \geq 0.39)$. Moreover, no significant effects of RPL $(P=0.14$ for total AA and $P>0.40$ for the other 11 traits) or for RPL $\times$ RPM interaction $(P \geq 0.38)$ were found, and these data are not reported. Although the 4 ruminally cannulated cows were fed all 8 diets over the course of

\begin{tabular}{|c|c|c|c|c|c|c|c|c|c|}
\hline \multirow[b]{2}{*}{ Trait } & \multicolumn{4}{|c|}{ Alfalfa silage } & \multicolumn{4}{|c|}{ Red clover silage } & \multirow[b]{2}{*}{$\mathrm{SEM}^{2}$} \\
\hline & Control & Met & Lys & Met + Lys & Control & Met & Lys & Met + Lys & \\
\hline DMI, kg/d & 24.1 & 24.4 & 23.8 & 23.6 & 21.8 & 23.2 & 22.7 & 23.0 & 0.41 \\
\hline BW gain, $\mathrm{kg} / \mathrm{d}$ & 0.33 & 0.42 & 0.41 & 0.39 & 0.31 & 0.33 & 0.39 & 0.46 & 0.116 \\
\hline Milk, $\mathrm{kg} / \mathrm{d}$ & 35.2 & 35.1 & 35.7 & 34.2 & 34.6 & 35.6 & 34.4 & 34.3 & 0.70 \\
\hline Milk/DMI & 1.48 & 1.44 & 1.50 & 1.45 & 1.61 & 1.54 & 1.53 & 1.50 & 0.029 \\
\hline Fat, $\%$ & 3.96 & 4.09 & 4.05 & 4.07 & 3.88 & 3.97 & 3.93 & 4.00 & 0.078 \\
\hline Fat, kg/d & 1.38 & 1.42 & 1.43 & 1.36 & 1.33 & 1.38 & 1.35 & 1.35 & 0.041 \\
\hline True protein, $\%$ & 3.00 & 3.08 & 2.99 & 3.11 & 2.95 & 3.02 & 3.01 & 3.04 & 0.035 \\
\hline True protein, $\mathrm{kg} / \mathrm{d}$ & 1.038 & 1.059 & 1.051 & 1.036 & 1.007 & 1.051 & 1.026 & 1.020 & 0.0230 \\
\hline Lactose, $\%$ & 4.80 & 4.78 & 4.81 & 4.78 & 4.85 & 4.88 & 4.83 & 4.88 & 0.027 \\
\hline Lactose, $\mathrm{kg} / \mathrm{d}$ & 1.67 & 1.67 & 1.71 & 1.61 & 1.66 & 1.70 & 1.66 & 1.64 & 0.039 \\
\hline $\mathrm{SNF}, \%$ & 8.71 & 8.77 & 8.70 & 8.81 & 8.69 & 8.80 & 8.74 & 8.81 & 0.045 \\
\hline \multicolumn{10}{|l|}{ N excretion ${ }^{4}$} \\
\hline Total urinary $\mathrm{N}, \mathrm{g} / \mathrm{d}$ & 182 & 178 & 185 & 182 & 149 & 133 & 151 & 155 & 5.5 \\
\hline Urea N/total N, \% & 80.7 & 84.8 & 82.2 & 80.6 & 79.1 & 79.7 & 80.7 & 77.3 & 2.53 \\
\hline Total urinary N, \% of NI & 29.3 & 28.6 & 30.7 & 30.8 & 27.1 & 23.5 & 26.8 & 27.0 & 0.93 \\
\hline Fecal N, g/d & 227 & 230 & 232 & 223 & 222 & 228 & 211 & 223 & 6.7 \\
\hline Fecal N, \% of NI & 36.6 & 37.0 & 38.2 & 36.9 & 40.1 & 39.4 & 37.3 & 38.8 & 0.76 \\
\hline Total $\mathrm{N}$ excretion, $\mathrm{g} / \mathrm{d}$ & 409 & 407 & 418 & 405 & 370 & 361 & 363 & 377 & 9.7 \\
\hline Total $\mathrm{N}$ excretion, $\%$ of NI & 65.9 & 65.6 & 68.7 & 67.7 & 67.2 & 63.0 & 64.1 & 65.9 & 1.21 \\
\hline
\end{tabular}
the trial, cannulated cows were fed AS and RCS in 2

Table 3. Least squares means for production and $\mathrm{N}$ excretion of lactating dairy cows fed the 8 individual dietary treatments ${ }^{1}$

${ }^{1}$ Control = no rumen-protected Met or rumen-protected Lys supplement; Met = supplementation with rumen-protected Met; Lys = supplementation with rumen-protected Lys; Met + Lys = supplementation with rumen-protected Met and rumen-protected Lys.

${ }^{2}$ Standard error of the least squares means.

${ }^{3} \mathrm{~N}$ intake.

${ }^{4}$ Urinary $\mathrm{N}$ excretion was estimated from creatinine concentration (Valadares et al., 1999), and fecal N excretion was estimated using indigestible $\mathrm{ADF}$ as an internal marker (Cochran et al., 1986). 
Table 4. Order in which legume silage treatments ${ }^{1}$ were fed to ruminally cannulated cows

\begin{tabular}{lllll}
\hline & \multicolumn{4}{c}{ Period } \\
\cline { 2 - 5 } $\begin{array}{l}\text { Cow } \\
\text { no. }\end{array}$ & 1 & 2 & 3 & 4 \\
\hline 1 & AS & AS & RCS & RCS \\
2 & RCS & RCS & AS & AS \\
3 & AS & RCS & AS & RCS \\
4 & RCS & AS & RCS & AS \\
\hline
\end{tabular}

${ }^{1} \mathrm{AS}=$ alfalfa silage; $\mathrm{RCS}=$ red clover silage.

different sequences: (1) 1 silage for 2 periods in a row before switching to the second silage for the remaining 2 periods, or (2) alternate silages fed every period (Table 4). Metabolite concentrations and $\mathrm{pH}$ were plotted against time of the day, and a single value for area under the curve was computed for each metabolite. The 8 time-weighted means observed on each silage were analyzed using the following model:

$$
\mathrm{Y}_{\mathrm{ijk} \mathrm{l}}=\mu+\mathrm{Seq}_{\mathrm{i}}+\mathrm{P}_{\mathrm{j}}+\mathrm{F}_{\mathrm{k}}+\mathrm{C}_{\mathrm{l}}\left(\mathrm{Seq}_{\mathrm{i}}\right)+\mathrm{E}_{\mathrm{ijk} \mathrm{k}},
$$

where $\mathrm{Y}_{\mathrm{ijkl}}=$ dependent variable, $\mu=$ overall mean, $\mathrm{Seq}_{\mathrm{i}}=$ effect of sequence $\mathrm{i}\left(\mathrm{i}=1\right.$ to 2 ), $\mathrm{P}_{\mathrm{j}}=$ effect of period $\mathrm{j}(\mathrm{j}=1$ to 4$), \mathrm{F}_{\mathrm{k}}=$ effect of forage $\mathrm{k}(\mathrm{k}=1$ to 2 , AS or RCS), $\mathrm{C}_{1}\left(\mathrm{Seq}_{\mathrm{i}}\right)=$ effect of cow 1 within sequence $\mathrm{i}$, and $\mathrm{E}_{\mathrm{ijkl}}=$ residual error. All terms were considered fixed except for $\mathrm{C}_{\mathrm{i}}\left(\mathrm{Seq}_{\mathrm{i}}\right)$ and $\mathrm{E}_{\mathrm{ijkl}}$, which were considered random.

It was assumed that RPM and RPL supplementation had no effect on nutrient digestibility. Effects of forage source on digestibility were assessed using the following model:

$$
\begin{aligned}
\mathrm{Y}_{\mathrm{ijk} \mathrm{k}}=\mu & +\mathrm{S}_{\mathrm{i}}+\mathrm{P}_{\mathrm{j}}+\mathrm{F}_{\mathrm{k}}+\mathrm{S} \times \mathrm{P}_{\mathrm{ij}}+\mathrm{S} \times \mathrm{F}_{\mathrm{ik}} \\
& +\mathrm{P} \times \mathrm{F}_{\mathrm{jk}}+\mathrm{C}_{\mathrm{l}}\left(\mathrm{S}_{\mathrm{i}}\right)+\mathrm{E}_{\mathrm{ijk}},
\end{aligned}
$$

where $\mathrm{Y}_{\mathrm{ijkl}}=$ dependent variable, $\mu=$ overall mean, $\mathrm{S}_{\mathrm{i}}$ $=$ effect of square $\mathrm{i}(\mathrm{i}=1$ to 6$), \mathrm{P}_{\mathrm{j}}=$ effect of period $\mathrm{j}(\mathrm{j}=1$ to 4$), \mathrm{F}_{\mathrm{k}}=$ effect of forage $\mathrm{k}(\mathrm{k}=1$ to 2 , AS or RCS), $\mathrm{S} \times \mathrm{P}_{\mathrm{ij}}=$ interaction of square and period, $\mathrm{S} \times \mathrm{F}_{\mathrm{ik}}=$ interaction of square and forage, $\mathrm{P} \times \mathrm{F}_{\mathrm{jk}}=$ interaction of period and forage, $\mathrm{C}_{1}\left(\mathrm{~S}_{\mathrm{i}}\right)=$ effect of cow 1 within square $\mathrm{i}$, and $\mathrm{E}_{\mathrm{ijk}}=$ residual error. All terms were considered fixed except for $\mathrm{C}_{\mathrm{l}}\left(\mathrm{S}_{\mathrm{i}}\right)$ and $\mathrm{E}_{\mathrm{ijk}}$, which were considered random.

Data from the lamb trials conducted with ad libitum and restricted feeding were analyzed separately using the following model:

$$
\mathrm{Y}_{\mathrm{ij}}=\mu+\mathrm{ER}_{\mathrm{i}}+\mathrm{F}_{\mathrm{j}}+\mathrm{ER} \times \mathrm{F}_{\mathrm{ij}}+\mathrm{E}_{\mathrm{ij}},
$$

where $Y_{\mathrm{ij}}=$ dependent variable, $\mu=$ overall mean, $\mathrm{ER}_{\mathrm{i}}$ $=$ effect of experimental replicate $\mathrm{i}(\mathrm{i}=1$ to 2$), \mathrm{F}_{\mathrm{j}}=$ effect of forage $\mathrm{j}$ ( $\mathrm{j}=1$ to 4 , AS or RCS replicate 1,2 , or 3), $\mathrm{ER} \times \mathrm{F}_{\mathrm{ij}}=$ interaction of experimental replicate $i$ and forage $j$, and $E_{i j}=$ residual error. All terms were considered fixed except for $\mathrm{E}_{\mathrm{ij}}$, which was considered random. Rather than reporting results for individual RCS, an orthogonal contrast was constructed to compare effects of feeding AS versus RCS.

\section{RESULTS}

\section{Lactation Trial}

The second-cutting AS fed in these studies contained about 3 percentage units more $\mathrm{CP}$ and a lower concentration of hemicellulose than the RCS, two-thirds of which came from the first cutting; however, harvests were timed such that NDF contents of AS and both RCS were similar (Table 1). The 2 silages were most different in composition of the $\mathrm{N}$ fractions: RCS contained greater concentrations of NDIN, ADIN, and N fraction B2 (NDIN - ADIN; Higgs et al., 2015) and about one-third less NPN as a proportion of total CP. Much of the difference in the NPN fraction was due to free AA. Low ammonia concentrations and low $\mathrm{pH}$ indicated that both AS and RCS were well fermented. Because of its greater CP content, the AS was diluted with grass silage when fed such that the blend of AS plus grass silage was comparable in $\mathrm{CP}$ with the RCS (Table 2). An additional 1 percentage unit of soybean meal DM also was added to the 4 RCS diets; although generally similar in chemical composition, the AS diets averaged $15.9 \% \mathrm{CP}$ and $31 \% \mathrm{NDF}$ versus $15.6 \% \mathrm{CP}$ and $29 \% \mathrm{NDF}$ for the RCS diets. The greater NDF content of AS diets was due to the greater NDF concentration in grass silage ( $57 \%$ of DM) versus AS and RCS (40 and 39\% of DM; Table 1). Proportions of total dietary $\mathrm{CP}$ contributed by legume silages averaged $62 \%$ for AS diets and $68 \%$ for RCS diets (Table 2). Nitrogen fraction B2 accounted for 10 and 19\% of total CP in AS- and RCS-based diets, respectively. Also note that ADIN represented more of the CP equivalent on RCS. The NRC (2001) model predicted substantially greater milk yield based on dietary $\mathrm{NE}_{\mathrm{L}}$ than $\mathrm{MP}$ content; $\mathrm{NE}_{\mathrm{L}}$-allowable milk was comparable with observed milk yield, but MP-allowable milk was more than $10 \mathrm{~kg} / \mathrm{d}$ less than observed milk yield (Table 3 ). Without either rumen-protected AA or with RPL alone, estimated Lys: Met ratio in MP ranged from 3.6 to 4.2; supplementation with RPM reduced the Lys:Met ratio to 2.8 to 3.3. The NRC (2001) model cites 3.0 as the optimum Lys: Met ratio, thus implicating Met as a first-limiting AA on both AS- and RCS-based diets. 
The overall effects of legume silage source on production traits are summarized in Table 5. Intake of DM was substantially greater on AS; however, cows produced similar milk at greater milk/DMI on RCS. Because of higher milk fat content, ECM yield was greater on AS, although ECM/DMI was still less than when cows were fed RCS. Milk true protein content was also greater and there was a trend for greater protein yield on AS versus RCS. However, MUN was substantially lower and milk $\mathrm{N} / \mathrm{N}$ intake was elevated on the RCS-based diets. This was related to reduced total urinary $\mathrm{N}$ excretion, virtually all of which was due to lower urinary urea, when dietary RCS replaced AS plus grass silage. Although fecal $\mathrm{N}$ excretion as a proportion of $\mathrm{N}$ intake was increased, the reduction in total $\mathrm{N}$ excretion was about equal to the improvement in milk $\mathrm{N} / \mathrm{N}$ intake on RCS. Additionally, milk lactose content was elevated on RCS.

Supplementation of both forages with RPM increased DMI and concentration of milk true protein and SNF, with most of the increase in SNF attributable to the effect on true protein (Table 5); however, true protein yield was not altered $(P=0.11)$. There was also a trend for increased milk fat content. The other effects observed with RPM feeding were reduced milk/DMI and a trend for reduced ECM/DMI; these occurred because milk and ECM yields were not affected despite increased DMI. The only effect detected with RPL supplementation was an elevation in urinary $\mathrm{N}$ excretion of $8 \mathrm{~g} / \mathrm{d}$. Because there was no change in milk protein secretion, all of the $\mathrm{N}$ in RPL would be excreted in the urine; on average, about $5 \mathrm{~g}$ of $\mathrm{N} / \mathrm{d}$ was consumed as chemical Lys in RPL in the trial.

A silage $\times$ RPM interaction was detected only for milk lactose concentration (Table 6); however, lactose secretion was not altered $(P=0.17)$. No other silage $\times$ RPM interaction was found, indicating that the effects of Met were similar on both AS and RCS. Several silage $\times$ RPL interactions were observed that were related to DMI: feeding RPL on AS-based diets appeared to reduce intake by $0.5 \mathrm{~kg} / \mathrm{d}$, whereas feeding RPL on RCSbased diets appeared to increase intake by the same

Table 5. Effect of source of legume silage and rumen-protected AA on least squares means for production and $\mathrm{N}$ excretion in lactating dairy cows $^{1}$

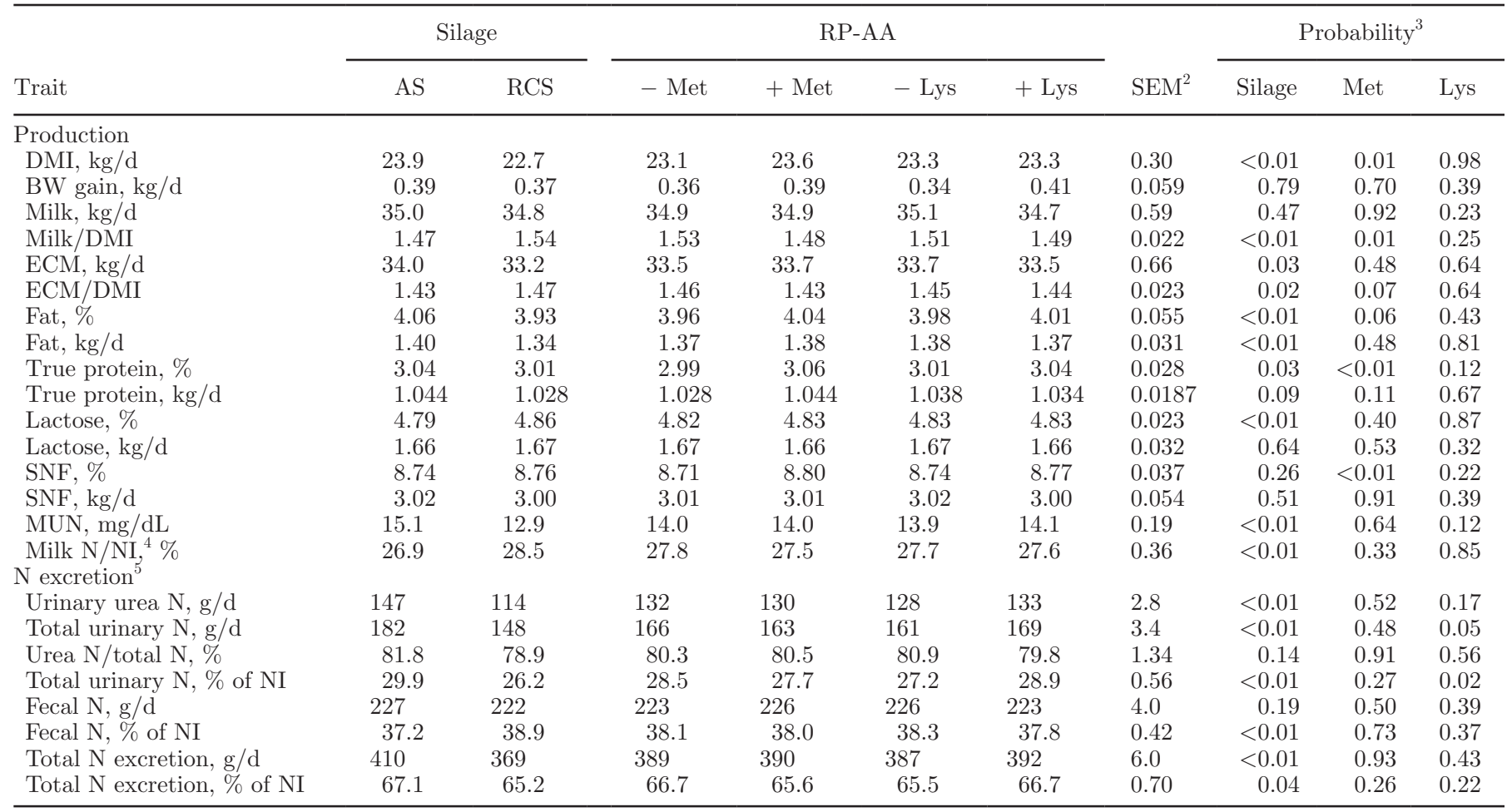

\footnotetext{
${ }^{1} \mathrm{AS}=$ alfalfa silage; $\mathrm{RCS}=$ red clover silage; $\mathrm{RP}-\mathrm{AA}=$ rumen-protected AA; - Met $=$ no rumen-protected Met; + Met $=$ rumen-protected Met; - Lys $=$ no rumen-protected Lys; + Lys = rumen-protected Lys.

${ }^{2}$ Standard error of the least squares means.

${ }^{3}$ Probability of effects of legume silage source, rumen-protected Met supplementation, and rumen-protected Lys supplementation.

${ }^{4} \mathrm{~N}$ intake.

${ }^{5}$ Urinary excretion estimated from creatinine concentration (Valadares et al., 1999) and fecal N excretion estimated using indigestible ADF as an internal marker (Cochran et al., 1986).
} 
amount. The reduced denominator resulted in interactions for milk/DMI, ECM/DMI, and fecal N expressed as a proportion of $\mathrm{N}$ intake when no interactions were detected for milk and ECM yield and amount of fecal $\mathrm{N}$ excretion. Trends for silage $\times$ RPL interactions were also detected for MUN, apparent $\mathrm{N}$ efficiency, and total $\mathrm{N}$ excretion that also were the inverse of that for DMI. Interactions of RPM $\times$ RPL were observed for yield of ECM, protein, lactose, and SNF that were related to the trend for an RPM $\times$ RPL interaction for milk yield (Table 7). All of these were numerically small changes in yield and may have little practical importance. These interactions reflected downward trends in milk and component yield when RPL supplemented RCS plus RPM.

Ruminal traits on AS- and RCS-based diets are in Table 8. There was a small reduction in propionate concentration on RCS, which gave rise to a trend for higher acetate:propionate ratio. Relative to AS, there were large reductions in concentrations of ammonia, total free AA, and the branched-chain VFA, all of which are products of protein degradation in the rumen (Van Soest, 1994). Data on nutrient digestibility, estimated using an internal marker, are in Table 9. Apparent digestibility of DM, OM, NDF, ADF, and hemicellulose on RCS-based diets was 3.5 to 6.5 percentage units greater than that of AS-based diets. On the other hand, apparent digestibility and estimated true digestibility of $\mathrm{N}$ (based on metabolic fecal $\mathrm{N}$ computed from DMI; NRC, 2001) were reduced, respectively, 1.8 and 1.2 percentage units on RCS.

\section{Lamb Digestion and Metabolism Trials}

Table 10 reports results obtained in the duplicated digestibility and metabolism trials conducted with growing wether lambs fed only AS or RCS as their total diet. Jung et al. (2011) proposed using growing

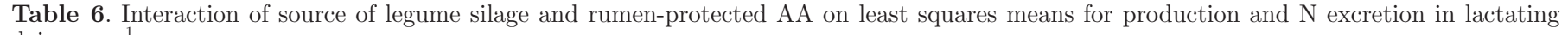
dairy cows ${ }^{1}$

\begin{tabular}{|c|c|c|c|c|c|c|c|c|c|c|c|}
\hline \multirow[b]{2}{*}{ Silage } & \multicolumn{2}{|c|}{$\mathrm{AS}$} & \multicolumn{2}{|c|}{ RCS } & \multicolumn{2}{|c|}{ AS } & \multicolumn{2}{|c|}{$\mathrm{RCS}$} & \multirow[b]{2}{*}{$\mathrm{SEM}^{2}$} & \multicolumn{2}{|c|}{ Probability $^{3}$} \\
\hline & - RPM & + RPM & - RPM & $+\mathrm{RPM}$ & $-\mathrm{RPL}$ & $+\mathrm{RPL}$ & $-\mathrm{RPL}$ & $+\mathrm{RPL}$ & & $\begin{array}{l}\text { Silage } \\
\times \text { RPM }\end{array}$ & $\begin{array}{l}\text { Silage } \\
\times \text { RPL }\end{array}$ \\
\hline \multicolumn{12}{|l|}{ Production } \\
\hline DMI, kg/d & 23.8 & 24.1 & 22.3 & 23.2 & 24.2 & 23.7 & 22.5 & 23.0 & 0.34 & 0.18 & 0.03 \\
\hline $\mathrm{BW}$ gain, $\mathrm{kg} / \mathrm{d}$ & 0.38 & 0.40 & 0.35 & 0.39 & 0.37 & 0.41 & 0.31 & 0.42 & 0.084 & 0.97 & 0.65 \\
\hline Milk, $\mathrm{kg} / \mathrm{d}$ & 35.2 & 34.8 & 34.6 & 35.0 & 35.1 & 35.0 & 35.1 & 34.4 & 0.64 & 0.18 & 0.39 \\
\hline Milk/DMI & 1.49 & 1.45 & 1.57 & 1.51 & 1.46 & 1.48 & 1.57 & 1.51 & 0.025 & 0.67 & 0.02 \\
\hline ECM, $\mathrm{kg} / \mathrm{d}$ & 34.0 & 34.0 & 32.9 & 33.5 & 34.0 & 34.0 & 33.4 & 33.0 & 0.71 & 0.38 & 0.55 \\
\hline ECM/DMI & 1.44 & 1.42 & 1.49 & 1.45 & 1.41 & 1.44 & 1.49 & 1.45 & 0.026 & 0.50 & 0.05 \\
\hline Fat, $\%$ & 4.02 & 4.10 & 3.89 & 3.97 & 4.05 & 4.08 & 3.91 & 3.95 & 0.063 & 0.99 & 1.00 \\
\hline Fat, $\mathrm{kg} / \mathrm{d}$ & 1.40 & 1.40 & 1.33 & 1.36 & 1.40 & 1.41 & 1.35 & 1.34 & 0.035 & 0.52 & 0.67 \\
\hline True protein, \% & 2.99 & 3.09 & 2.98 & 3.04 & 3.04 & 3.05 & 2.99 & 3.03 & 0.030 & 0.17 & 0.37 \\
\hline True protein, $\mathrm{kg} / \mathrm{d}$ & 1.038 & 1.051 & 1.019 & 1.037 & 1.045 & 1.044 & 1.031 & 1.024 & 0.0198 & 0.74 & 0.76 \\
\hline Lactose, \% & 4.80 & 4.78 & 4.84 & 4.88 & 4.79 & 4.80 & 4.87 & 4.85 & 0.024 & $<0.01$ & 0.36 \\
\hline Lactose, $\mathrm{kg} / \mathrm{d}$ & 1.68 & 1.65 & 1.66 & 1.68 & 1.66 & 1.66 & 1.69 & 1.65 & 0.035 & 0.17 & 0.39 \\
\hline SNF, $\%$ & 8.71 & 8.78 & 8.72 & 8.81 & 8.74 & 8.75 & 8.75 & 8.78 & 0.039 & 0.61 & 0.68 \\
\hline $\mathrm{SNF}, \mathrm{kg} / \mathrm{d}$ & 3.03 & 3.01 & 2.99 & 3.02 & 3.02 & 3.02 & 3.02 & 2.98 & 0.058 & 0.36 & 0.51 \\
\hline MUN, mg/dL & 15.1 & 15.1 & 12.9 & 13.0 & 14.9 & 15.3 & 12.9 & 12.9 & 0.22 & 0.66 & 0.07 \\
\hline Milk N/NI, ${ }^{4} \%$ & 26.8 & 26.9 & 28.8 & 28.1 & 26.6 & 27.1 & 28.8 & 28.2 & 0.43 & 0.22 & 0.06 \\
\hline \multicolumn{12}{|l|}{$\mathrm{N}$ excretion ${ }^{5}$} \\
\hline Urinary urea N, g/d & 147 & 148 & 116 & 112 & 146 & 149 & 111 & 117 & 3.7 & 0.42 & 0.56 \\
\hline Total urinary $\mathrm{N}, \mathrm{g} / \mathrm{d}$ & 183 & 181 & 150 & 146 & 180 & 185 & 142 & 153 & 4.6 & 0.84 & 0.52 \\
\hline Urea N/total N, \% & 80.8 & 82.7 & 79.7 & 78.2 & 82.7 & 80.8 & 79.1 & 78.8 & 1.92 & 0.39 & 0.68 \\
\hline Total urinary $\mathrm{N}, \%$ of $\mathrm{NI}$ & 30.0 & 29.8 & 26.9 & 25.5 & 28.9 & 30.9 & 25.6 & 26.9 & 0.76 & 0.38 & 0.65 \\
\hline Fecal N, g/d & 229 & 226 & 217 & 226 & 227 & 228 & 226 & 218 & 5.1 & 0.13 & 0.32 \\
\hline Fecal N, \% of NI & 37.5 & 36.9 & 38.8 & 39.0 & 36.8 & 37.6 & 39.8 & 38.0 & 0.59 & 0.45 & 0.02 \\
\hline Total N excretion, g/d & 412 & 407 & 366 & 372 & 406 & 413 & 368 & 371 & 7.6 & 0.39 & 0.76 \\
\hline Total $\mathrm{N}$ excretion, $\%$ of NI & 67.5 & 66.7 & 65.8 & 64.5 & 65.7 & 68.5 & 65.4 & 64.9 & 0.97 & 0.82 & 0.09 \\
\hline
\end{tabular}

$\overline{{ }^{1} \mathrm{AS}}=$ alfalfa silage; $\mathrm{RCS}=$ red clover silage; $\mathrm{RPM}=$ rumen-protected Met; $\mathrm{RPL}=$ rumen-protected Lys. For RPM, $-=$ no $\mathrm{RPM}$ and $+=$ RPM supplemented. For RPL, $-=$ no RPL and $+=$ RPL supplemented.

${ }^{2}$ Standard error of the least squares means.

${ }^{3}$ Probability of interaction of legume silage source $\times$ RPM supplementation and legume silage source $\times$ RPL supplementation.

${ }^{4} \mathrm{~N}$ intake.

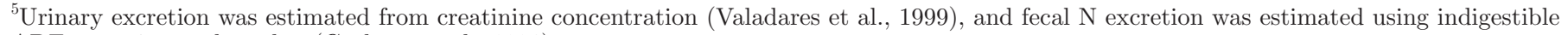
ADF as an internal marker (Cochran et al., 1986). 
Table 7. Interaction of rumen-protected AA on least squares means for production and $\mathrm{N}$ excretion in lactating dairy cows ${ }^{1}$

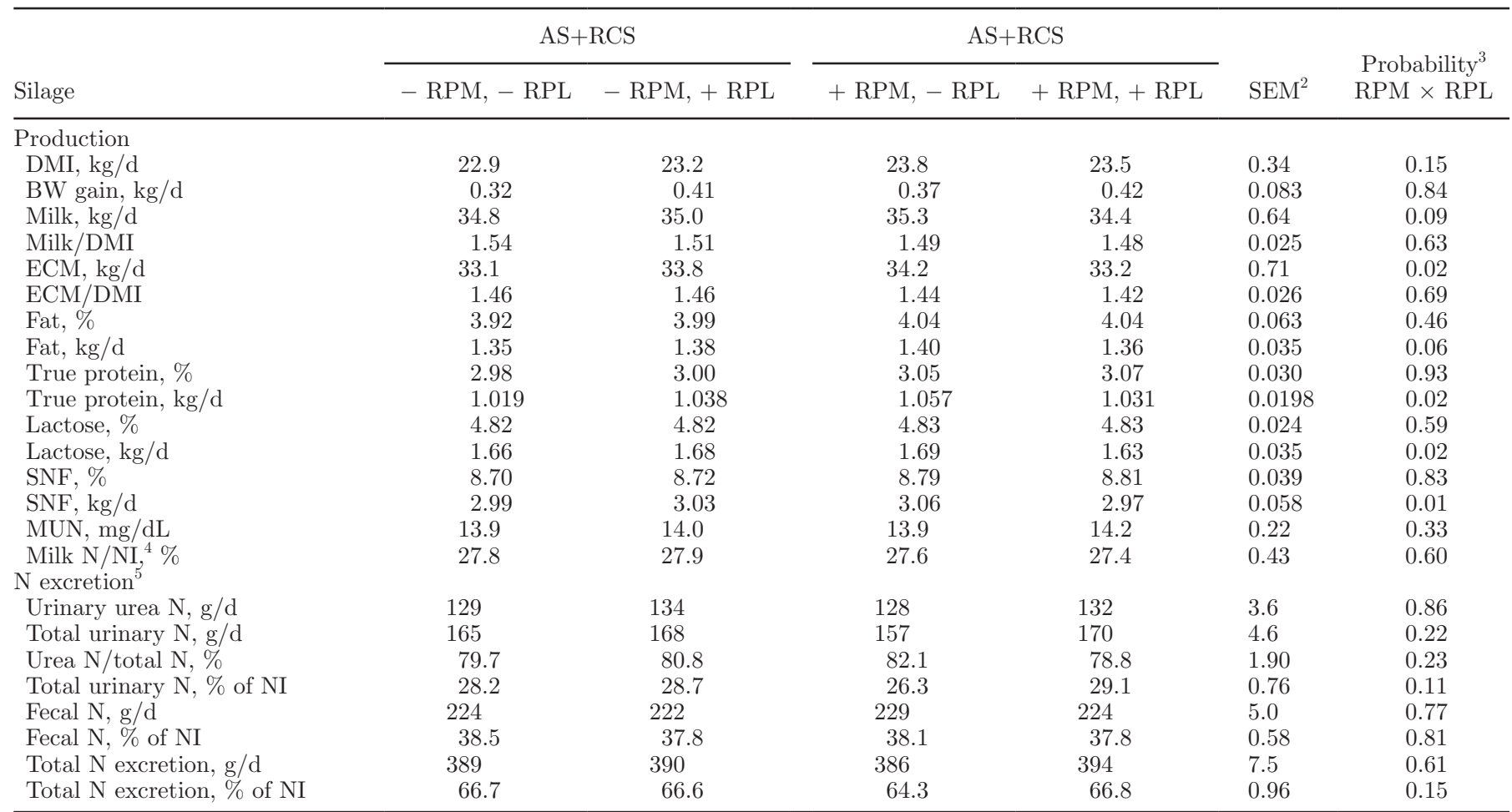

${ }^{1} \mathrm{AS}=$ alfalfa silage; $\mathrm{RCS}=$ red clover silage; $\mathrm{RPM}=$ rumen-protected Met; RPL $=$ rumen-protected Lys. For RPM, $-=$ no RPM and $+=$ RPM supplemented. For RPL,$-=$ no RPL and $+=$ RPL supplemented.

${ }^{2}$ Standard error of the least squares means.

${ }^{3}$ Probability of interaction of RPM and RPL supplementation.

${ }^{4} \mathrm{~N}$ intake.

${ }^{5}$ Urinary excretion estimated from creatinine concentration (Valadares et al., 1999) and fecal N excretion estimated using indigestible ADF as an internal marker (Cochran et al., 1986).

lambs as a digestion and metabolism model for lactating cows because of similar DMI on a BW basis; ad libitum DMI of lambs and cows in the current trial was, respectively, 4.1 and $4.2 \%$ of BW. Intake of DM, $\mathrm{OM}$, and NDF was not different between AS and RCS in either the ad libitum or restricted intake trials; how-

Table 8. Effects of source of dietary legume silage on ruminal traits

\begin{tabular}{|c|c|c|c|c|}
\hline \multirow[b]{2}{*}{ Trait } & \multicolumn{2}{|c|}{ Silage } & \multirow[b]{2}{*}{$\mathrm{SEM}^{1}$} & \multirow[b]{2}{*}{ Probability $^{2}$} \\
\hline & Alfalfa & Red clover & & \\
\hline $\mathrm{pH}$ & 6.67 & 6.75 & 0.021 & 0.06 \\
\hline Ammonia $\mathrm{N}, \mathrm{mg} / \mathrm{dL}$ & 7.47 & 4.42 & 0.480 & 0.01 \\
\hline Total AA, mM & 1.66 & 1.18 & 0.323 & 0.01 \\
\hline Total VFA, $\mathrm{m} M$ & 79.8 & 75.6 & 1.85 & 0.18 \\
\hline Acetate, $\mathrm{m} M$ & 52.2 & 50.4 & 1.09 & 0.30 \\
\hline Propionate, $\mathrm{m} M$ & 15.4 & 14.2 & 0.84 & 0.03 \\
\hline Acetate:propionate ratio & 3.41 & 3.55 & 0.162 & 0.06 \\
\hline Butyrate, $\mathrm{m} M$ & 8.4 & 7.8 & 0.32 & 0.26 \\
\hline Isobutyrate, $\mathrm{m} M$ & 0.99 & 0.81 & 0.023 & 0.01 \\
\hline Isovalerate +2 -methyl butyrate, $\mathrm{m} M$ & 1.49 & 1.23 & 0.057 & $<0.01$ \\
\hline Branched-chain VFA, ${ }^{3} \mathrm{~m} M$ & 2.48 & 2.04 & 0.053 & $<0.01$ \\
\hline Valerate, $\mathrm{m} M$ & 1.31 & 1.18 & 0.045 & 0.12 \\
\hline
\end{tabular}


BRODERICK

Table 9. Effects of source of dietary legume silage on digestibility

\begin{tabular}{lcccc}
\hline & \multicolumn{2}{c}{ Silage } & \\
\cline { 2 - 2 } Trait & Alfalfa & Red clover & SEM $^{1}$ & Probability $^{2}$ \\
\hline Apparent digestibility, ${ }^{3} \%$ & 61.3 & 65.2 & 0.31 & $<0.01$ \\
DM & 62.7 & 66.6 & 0.30 & $<0.01$ \\
OM & 44.0 & 49.5 & 0.45 & $<0.01$ \\
NDF & 45.8 & 52.3 & 0.43 & $<0.01$ \\
ADF & 39.8 & 43.3 & 0.52 & $<0.01$ \\
Hemicellulose & 62.8 & 61.2 & 0.42 & $<0.01$ \\
N & 81.7 & 80.4 & 0.42 & 0.02 \\
Estimated true N digestibility, ${ }^{4} \%$ & & & & \\
${ }^{1}$ Standard error of the least squares means. & & & \\
${ }^{2}$ Probability of a significant effect of feeding alfalfa silage versus red clover silage. \\
${ }^{3}$ Apparent digestibility was estimated using indigestible ADF as an internal marker (Cochran et al., 1986). \\
${ }^{4}$ True N digestibility was estimated assuming metabolic fecal N = 4.8 g of N/kg of DMI per day (NRC, 2001).
\end{tabular}

ever, consumption of ADF, hemicellulose, and $\mathrm{N}$ was greater on AS because of lower concentrations of these nutrients in RCS. Although apparent digestibility of $\mathrm{DM}, \mathrm{OM}$, and $\mathrm{ADF}$ was not different, digestibility of $\mathrm{NDF}$ and hemicellulose was greater in lambs fed RCS versus AS at ad libitum silage intake. Moreover, apparent digestibility of DM, OM, and all fiber components was greater in lambs fed RCS versus AS at restricted intake. When RCS was fed, apparent N digestibility at ad libitum and restricted intake was reduced 15 and 11 percentage units, respectively, and estimated true $\mathrm{N}$ digestibility (computed assuming metabolic fecal $\mathrm{N}=$
$5 \mathrm{~g} / \mathrm{kg}$ of DMI; Corbett and Ball, 2002) at ad libitum and restricted intake was reduced 13 and 10 percentage units, respectively. As a proportion of $\mathrm{N}$ intake, urinary $\mathrm{N}$ excretion in lambs was about 10 (ad libitum) and 5 (restricted) percentage units lower on RCS; however, fecal $\mathrm{N}$ excretion averaged about 16 (ad libitum) and 11 (restricted) percentage units higher on RCS. This resulted in greater total $\mathrm{N}$ excretion on RCS at both ad libitum and restricted intake and, as a proportion of $\mathrm{N}$ intake, $\mathrm{N}$ retention was 6 percentage units greater on AS in growing wether lambs fed diets consisting only of legume silage.

Table 10. Effect of ad libitum or restricted intake of alfalfa silage (AS) or red clover silage (RCS) on intake, digestibility, and N utilization by growing lambs ${ }^{1}$

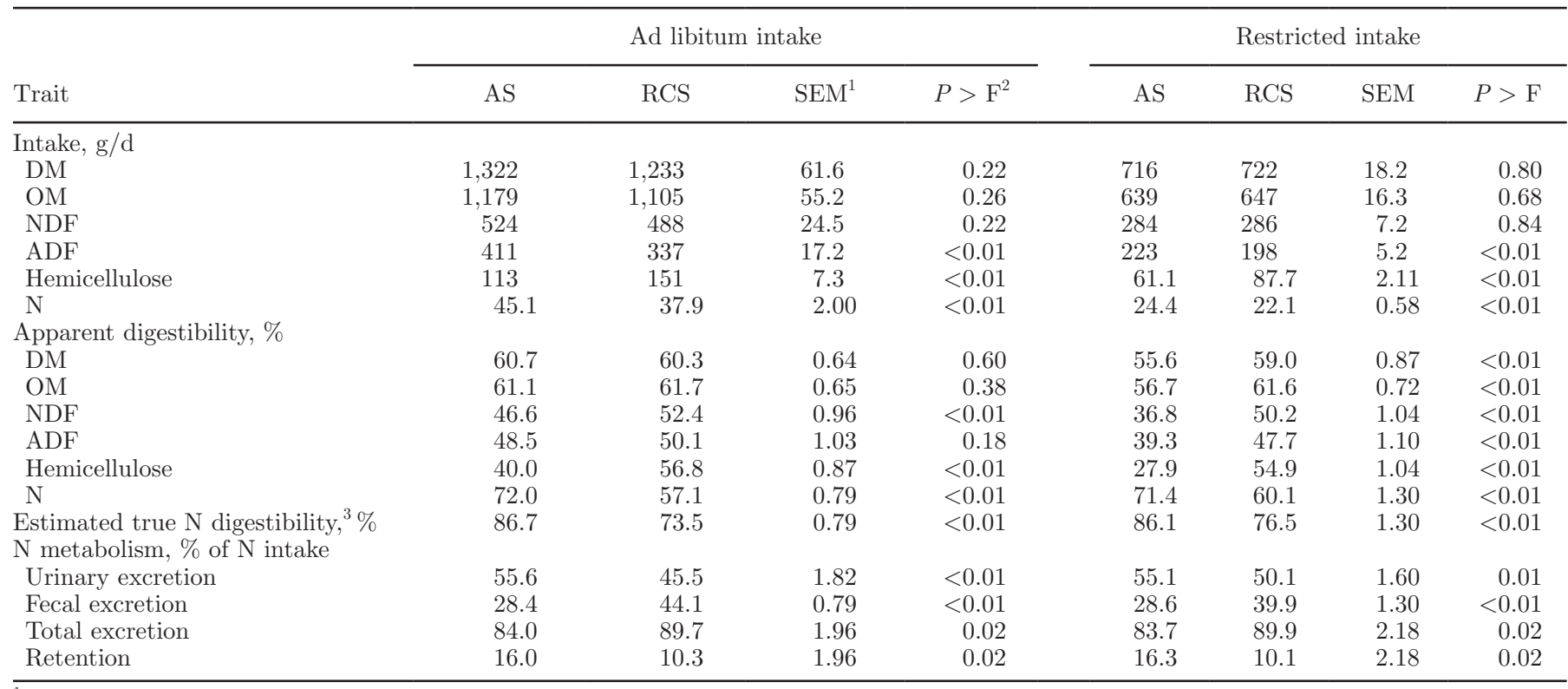

${ }^{1}$ Standard error of the least squares means.

${ }^{2}$ Probability of a significant effect of feeding alfalfa silage versus red clover silage.

${ }^{3}$ True $\mathrm{N}$ digestibility estimated assuming metabolic fecal $\mathrm{N}=5 \mathrm{~g}$ of N/kg of DMI per day (Corbett and Ball, 2002). 


\section{DISCUSSION}

Because AS with NDF content similar to the RCS was not available from the first cutting, AS from the second cutting was fed in this trial. Feeding AS and RCS with similar NDF contents was done in our previous comparisons (e.g., Broderick, 2002). Huhtanen et al. (2007) found in an extensive literature review that average DM digestibility was greater for first- than second-cutting forages, an effect that may confound interpretation of the current results. Reduced DM digestibility might be due to increased forage fiber content. Brink et al. (2016) observed that NDF concentration in alfalfa and red clover DM increased by 4.3 and 7.6 percentage units from first to second cutting. However, Clavin et al. (2016) reported that, for 1 of 2 red clover cultivars, mean DM digestibility over 6 harvest years did not decline from first to second cutting. The NDF contents of AS and RCS fed in the present study were, respectively, 40 and $39 \%$ of $\mathrm{DM}$.

Although yield of milk and most milk components was not altered by legume silage source in this trial, greater ECM yield was observed due to increased milk fat content and yield on AS (Table 5). Reduced milk fat content and secretion by cows fed RCS have been observed in several studies. Hoffman et al. (1997) reported lower yields of fat and 4\% FCM on RCS versus AS in 1 of 2 trials comparing the forages. Our 5-trial summary showed, compared with AS, lower milk fat content and trends for reduced fat yield and increased BW gain on RCS (Broderick, 2002). Broderick et al. (2007) also found reduced fat yield on RCS in 1 trial where DMI was not different from AS and reduced milk fat content and yield on RCS in a second trial where DMI was lower than AS. Steinshamn (2010) summarized data showing that replacing AS with RCS resulted in numeric, but not significant, reductions in milk fat concentration and yield. Moorby et al. (2009) reported that incremental replacement of dietary grass silage with RCS gave a linear decrease in milk fat concentration and a linear increase in the content of C18:2n- 6 and C18:3n-3 fatty acids in milk fat, although there was no change in milk fat yield because milk yield was increased. HalmemiesBeauchet-Filleau et al. (2014) found that incrementally replacing grass silage with RCS linearly increased milk C18:2n-6 and C18:3n-3 and linearly decreased milk C4:0, C8:0, and C14:0, 3 fatty acids that derive only from de novo synthesis (Bauman and Griinari, 2003); however, milk fat concentration and yield also were not reduced in this study. Moreover, Dewhurst et al. (2006) summarized literature indicating that feeding RCS rather than grass silage increased incorporation into milk fat of UFA, notably C18:2n-6 and C18:2n-3. The presence of UFA in milk fat has been correlated with the formation of CLA, which are involved in milk fat depression (Bauman and Griinari, 2003).

As observed in our previous studies (Broderick, 2002; Broderick et al., 2007), RCS contained less CP but greater concentrations of hemicellulose, NDIN, ADIN, and $\mathrm{N}$ fraction B2 (NDIN - ADIN) when harvested at similar NDF content as AS (Table 1). Hoffman et al. (1993) reported that alfalfa forage averaged 2 percentage units more $\mathrm{CP}$ than red clover when harvested at the same growth stage. Moreover, NPN accounted for about one-third less total CP in RCS. Papadopoulos and McKersie (1983) observed that red clover gave rise to the lowest, and alfalfa the highest, levels of NPN during wilting and ensiling of 5 legume species. Several reports (e.g., Muck, 1987; Albrecht and Muck, 1991; Broderick, 2002) showed that elevated NDIN formation was associated with the lower NPN formation in RCS. Reduced NPN does not result from inherently lower proteolytic activity (Jones et al., 1995a) or more rapid pH decline during ensiling (Jones et al., 1995c). Rather, enzymatic browning due to PPO activity and o-diphenols, both of which are present in red clover tissue in high amounts, react with $\mathrm{O}_{2}$ to form o-quinones that rapidly interact with proteins, including the plant proteases, to inhibit proteolysis (Sullivan and Hatfield, 2006). Jones et al. (1995b) evaluated 38 legumes, including alfalfa, and found that only red clover had measurable PPO activity and gave rise to browning. Improved $\mathrm{N}$ utilization is associated with elevated $\mathrm{N}$ fraction $\mathrm{B} 2$ and reduced proportions of silage NPN (Nagel and Broderick, 1992; Brito et al., 2007). The $\mathrm{N}$ fraction B2 is the protein fraction assigned the slowest ruminal degradation rate in the Cornell model (Van Amburgh et al., 2015).

Despite greater milk $\mathrm{N} / \mathrm{N}$ intake and lower MUN, indicating improved $\mathrm{N}$ utilization (Nousiainen et al., 2004), lower NPN, greater N fraction B2, reduced protein degradation as evidenced by lower ruminal ammonia, free AA, and BCVFA (Table 8), all indicating greater RUP (Brito et al., 2007), the lactation response to replacing AS with RCS was disappointing. There are at least 4 possible explanations: (1) lower DMI commonly observed on RCS, which may reduce $\mathrm{NE}_{\mathrm{L}}$ supply; (2) reduced microbial protein synthesis on RCS-based diets; (3) impaired intestinal digestibility of RUP contributed by RCS; and (4) unbalanced AA pattern in MP provided by RCS. At average DMI (Table 5), dietary OM content (Table 2), and OM digestibility (Table 9), digestible OM intakes were 14.0 and 13.8 $\mathrm{kg} / \mathrm{d}$ on AS- and RCS-based diets, respectively. Assuming $0.749 \mathrm{Mcal}$ of $\mathrm{NE}_{\mathrm{L}} / \mathrm{kg}$ of ECM, $6.98 \mathrm{Mcal} / \mathrm{kg}$ of BW gain, and maintenance requirement of $9.45 \mathrm{Mcal} / \mathrm{d}$ at mean $\mathrm{BW}=580 \mathrm{~kg}$ (NRC, 2001), the AS diets provided 37.5 Mcal of $\mathrm{NE}_{\mathrm{L}} / \mathrm{d}$, equivalent to $(37.5 / 23.9)$ 1.56 Mcal of $\mathrm{NE}_{\mathrm{L}} / \mathrm{kg}$ of $\mathrm{DM}$, and RCS diets provided 
36.8 Mcal of $\mathrm{NE}_{\mathrm{L}} / \mathrm{d}$, equivalent to $(36.8 / 22.7) 1.62$ Mcal of $\mathrm{NE}_{\mathrm{L}} / \mathrm{kg}$ of DM. The difference of $0.8 \mathrm{~kg}$ of $\mathrm{ECM} / \mathrm{d}$ between AS and RCS would correspond to (0.8 $\times 0.749 / 1.62)$ about $0.4 \mathrm{~kg}$ of $\mathrm{DM} / \mathrm{d}$ of the RCS diet versus the observed DMI difference of $1.2 \mathrm{~kg} / \mathrm{d}$ (Table $5)$. These computations suggested that lower intake did not account for the lower production on the RCS diets.

The reduced DMI commonly seen when RCS replaces AS in the diet of lactating dairy cows is not observed when RCS replaces dietary grass silage (e.g., Huhtanen et al., 2007). Dewhurst et al. (2003a) found that rumen fill of both fresh matter and DM was lower in cows fed AS, indicating more rapid ruminal passage on AS. Protein status is also a factor regulating feed intake. Ouellet and Chiquette (2016) observed that an $11 \%$ reduction in estimated MP supply reduced DMI by $5 \%$. Zanton (2016) summarized the literature indicating that $\mathrm{CP}$ intake is directly related to DMI in lactating cows. Huhtanen et al. (2011) suggested that this influence might be explained as a "pull effect," whereby improved MP and metabolizable AA status increase yield of milk and milk components, which in turn stimulates feed intake. However, dietary essential AA pattern has been shown to directly influence feed intake in rats and birds, and the neurological system that senses imbalanced blood AA patterns has been found throughout the animal kingdom (Gietzen and Rogers, 2006). Moreover, Giallongo et al. (2017) observed that feeding a diet with inadequate supply of metabolizable His depressed His in blood plasma from 91 to $37 \mu M$ and reduced feed intake and milk protein yield by 9 and $6 \%$, respectively.

Intake of both fermentable energy and RDP influences microbial protein formation in the rumen. Greater $\mathrm{OM}$ and fiber digestibility on RCS versus AS has been a consistent observation in many studies (Hoffman et al., 1993; Broderick, 2002; Brito et al., 2007; Broderick et al., 2007). Dewhurst (2013) summarized data showing that RCS has greater net energy value than AS over a range of harvest maturities. Mean intake of digested $\mathrm{OM}$ and total VFA concentrations (Table 8) were similar on diets containing both legume silages, despite lower DMI on RCS, suggesting comparable fermentable energy supply. Lower concentrations of protein breakdown products indicated that RDP supply was reduced on RCS. Although mean ammonia concentration approximated $5 \mathrm{mg}$ of N/dL, the level of adequacy identified by Satter and Slyter (1974), Brito et al. (2007) reported lower microbial NAN yield per unit of OM truly fermented in the rumen and lower omasal flow of microbial NAN when RCS replaced AS in the diet. Replacing solvent soybean meal with higher RUP proteins is known to limit microbial protein formation in the rumen due to reduced RDP supply (Santos et al.,
1998). Moreover, peptides and AA are also important N sources for microbial growth (Russell et al., 1992; Hristov and Broderick, 1994), and ruminal concentrations of total AA were lower on RCS. Thus, reduced microbial protein formation due to insufficient RDP, rather than lower DMI, on the RCS-based diets cannot be excluded in the present study.

Compared with AS, apparent and estimated true N digestibility were somewhat reduced on RCS in lactating cows (Table 9). The RCS-based diets in the lactation trial averaged 1.1 percentage unit higher in ADIN, which may be compared with the decrease in true $\mathrm{N}$ digestibility of 1.4 percentage unit, indicating that $\mathrm{N}$ bound in the ADIN fraction accounted for most of the depression in N digestion (Van Soest, 1994). However, apparent and estimated true $\mathrm{N}$ digestibility were dramatically lower at both ad libitum and restricted intakes in lambs fed only RCS (Table 10); note that ADIN was only 2.4 percentage units greater in RCS versus AS (Table 1). Huhtanen and Broderick (2016) summarized data showing that replacing grass silage with RCS increased fecal $\mathrm{N}$ excretion at equivalent $\mathrm{CP}$ intakes in lambs fed at maintenance. Dewhurst et al. (2003b) and Vanhatalo et al. (2009) both observed no change in milk protein secretion in lactating cows fed RCS despite substantial increases in NAN flow from the rumen. Gidlund et al. (2017) recently reported that feeding RCS-based diets resulted in secretion of milk with lower protein content despite 1.5 to 2.0 percentage unit higher $\mathrm{CP}$ content in diets of the same composition except with RCS replacing grass silage. The literature and present experiments strongly indicate impaired intestinal digestibility of the RUP deriving from RCS.

Supplementation of RPM and RPL was used in the lactation trial in an attempt to determine whether Lys was more limiting than Met on the RCS-based diets. Although milk true protein yield was not altered by RPM supplementation $(P=0.11)$, increases in milk concentration of true protein and SNF (Tables 5) suggested that Met was limiting on both legume silages. Response of milk protein concentration to supplementation of the limiting AA is more sensitive than the response of milk protein yield (Socha et al., 2008). For example, the breakpoint fits to Met supplementation of milk protein concentration and milk protein secretion yielded an $\mathrm{R}^{2}$ of 0.76 and 0.40 , respectively (NRC, 2001). This finding was also consistent with several previous reports (Patton, 2010; Zanton et al., 2014). That cows responded to RPM, but not RPL, indicated that the specific reaction of the PPO enzyme system with Lys residues in protein (Prigent et al., 2008) did not change the order of AA limitation. Although mean omasal RUP flow was $48 \%$ greater on RCS than on grass silage, Vanhatalo et al. (2009) observed that concentrations of both Met and 
Cys in omasal digesta protein were reduced when RCS replaced grass silage. Vanhatalo et al. (2009) concluded that utilization of RCS protein was restricted because of relatively low Met content of its RUP. Purwin et al. (2015) determined AA contents of alfalfa and red clover before and after ensiling in large round bales; although no direct effect of ensiling on silage Met content was detected, Met concentration was substantially greater in AS than in RCS. Thus, impaired utilization of MP on RCS-based diets may be partly due to lowered Met supply.

Compared with AS, N retention was also reduced an average of $37 \%$ on RCS at both ad libitum and restricted feeding in growing lambs. The Met and Lys contents in essential AA profiles of milk and lean tissue proteins are similar (NRC, 2001) and the sulfur-AA requirement for wool growth is small in meat-type lambs relative to AA requirements for tissue growth (Oddy and Sainz, 2002). Thus, it may be presumed that, as well as for milk protein secretion, $\mathrm{N}$ retention in lambs might be restricted by intestinal Met absorption. Impaired $\mathrm{N}$ utilization in growing wethers was due to urinary $\mathrm{N}$ excretion in lambs not being reduced to the same extent that fecal $\mathrm{N}$ excretion was increased. This suggested that intestinal digestion of RUP from RCS, rather than the AA pattern of that RUP, limited its utilization in these trials. This explanation could be tested in lamb metabolism trials using RPM.

\section{CONCLUSIONS}

When RCS was compared with AS in the diets of lactating cows, replacing AS with RCS did not alter milk yield, increased milk/DMI, and reduced DMI and fat yield, which reduced ECM yield. A lack of response to RPL indicated that PPO action in RCS did not result in Lys becoming limiting. Moreover, increased milk concentrations of fat, true protein, and SNF on RPM suggested that Met was a first-limiting AA on both AS and RCS diets; however, Met was not limiting on these diets based on lack of response of yield of milk and milk components and nutrient efficiency. No inference can be made on whether Met bioavailability was reduced by PPO in RCS. Despite a large reduction in MUN and urinary $\mathrm{N}$ excretion, only a small reduction in estimated true $\mathrm{N}$ digestibility, and increased apparent $\mathrm{N}$ efficiency on RCS, milk protein content and yield were lower on RCS. Greater milk/DMI and ECM/DMI were likely driven by greater digestibility of $\mathrm{OM}$ and fiber on the RCS diet. Large reductions in estimated true $\mathrm{N}$ digestibility in growing lambs fed only RCS indicated that there was substantial depression in intestinal digestibility of RUP from RCS.

\section{ACKNOWLEDGMENTS}

The author thanks Rick Walgenbach and the farm crew for harvesting and storing the forages and Nancy Betzold and her barn crew at the US Dairy Forage Research Center Farm (Prairie du Sac, WI) for feeding and animal care during this trial; Daniel Luchini of Adisseo Corp. (Alpharetta, GA) for the gift of Smartamine-M; Michael de Veth of Balchem Corp. (New Hampton, NY) for the gift of AminoShure-L; Mike Boettcher and Wendy Radloff of the US Dairy Forage Research Center (Madison, WI) and Marina Danes and Nelson Lobos of the University of Wisconsin-Madison for preparing compressed silage bales; Jane Marita of the US Dairy Forage Research Center (Madison, WI) and Terry Jobsis of the University of Wisconsin-Madison for assisting with organization of the lamb feeding trials; Emilie Cerny of the University of Wisconsin-Madison for help with care and feeding of the lambs; Wendy Radloff and Mary Becker of the US Dairy Forage Research Center for laboratory analyses; and Peter Crump of the University of Wisconsin-Madison for assisting with statistical analyses. Mention of any trademark or proprietary product in this paper does not constitute a guarantee or warranty of the product by the USDA or the Agricultural Research Service and does not imply its approval to the exclusion of other products that also may be suitable.

\section{REFERENCES}

Albrecht, K. A., and R. E. Muck. 1991. Proteolysis in ensiled forage legumes that vary in tannin concentration. Crop Sci. 31:464-469.

AOAC. 1980. Official Methods of Analysis. 13th ed. Association of Official Analytical Chemists, Washington, DC.

AOAC. 1990. Official Methods of Analysis. 15th ed. Association of Official Analytical Chemists, Arlington, VA.

AOAC International. 1997. Official Methods of Analysis. 16th ed. AOAC International, Arlington, VA.

Bauman, D. E., and J. M. Griinari. 2003. Nutritional regulation of milk fat synthesis. Annu. Rev. Nutr. 23:203-227.

Brink, G. E., M. A. Sanderson, and M. D. Casler. 2016. Grass and legume effects on nutritive value of complex forage mixtures. Crop Sci. 55:1329-1337.

Brito, A. F., G. A. Broderick, J. J. Olmos Colmenero, and S. M. Reynal. 2007. Effects of feeding formate-treated alfalfa silage or red clover silage on omasal nutrient flow and microbial protein synthesis in lactating dairy cows. J. Dairy Sci. 90:1392-1404.

Broderick, G. A. 1987. Determination of protein degradation rates using a rumen in vitro system containing inhibitors of microbial nitrogen metabolism. Br. J. Nutr. 58:463-475.

Broderick, G. A. 2002. An analysis of the relative value of lucerne and red clover silages for lactating cows. Pages 128-129 in Proc. 13th Int. Silage Conf. L. M. Gechie and C. Thomas, ed. Scottish Agricultural College, Auchincruive, Ayr KA6 5HW, Scotland.

Broderick, G. A., A. F. Brito, and J. J. Olmos Colmenero. 2007. Effects of feeding formate-treated alfalfa silage or red clover silage on the production of lactating dairy cows. J. Dairy Sci. 90:1378-1391.

Broderick, G. A., and M. K. Clayton. 1997. A statistical evaluation of animal and nutritional factors influencing concentrations of milk urea nitrogen. J. Dairy Sci. 80:2964-2971. 
Broderick, G. A., A. P. Faciola, and L. E. Armentano. 2015. Replacing dietary soybean meal with canola meal improves production and efficiency of lactating dairy cows. J. Dairy Sci. 98:5672-5687.

Clavin, D., P. Crosson, J. Grant, and P. O'Kiely. 2016. Red clover for silage: Management impacts on herbage yield, nutritive value, ensilability and persistence, and relativity to perennial ryegrass. Grass Forage Sci. 72:414-431.

Cochran, R. C., D. C. Adams, J. D. Wallace, and M. L. Galyean. 1986. Predicting digestibility of different diet with internal markers: Evaluation of four potential markers. J. Anim. Sci. 63:1476-1487.

Colmenero, J. J., and G. A. Broderick. 2006. Effect of dietary crude protein concentration on milk production and nitrogen utilization in lactating dairy cows. J. Dairy Sci. 89:1704-1712.

Corbett, J. L., and A. J. Ball. 2002. Nutrition for maintenance. Pages 143-163 in Sheep Nutrition. M. Freer and H. Dove, ed. CABI and CSIRO, Wallingford, UK.

Davis, A. W., and W. B. Hall. 1969. Cyclic change-over designs. Biometrics 56:283-293.

Dewhurst, R. J. 2013. Milk production from silage: Comparison of grass, legume and maize silages and their mixtures. Agric. Food Sci. 22:57-69.

Dewhurst, R. J., R. T. Evans, N. D. Scollan, J. M. Moorby, R. J. Merry, and R. J. Wilkins. 2003a. Comparison of grass and legume silages for milk production. 2. In vivo and in sacco evaluations of rumen function. J. Dairy Sci. 86:2612-2621.

Dewhurst, R. J., W. J. Fisher, J. K. S. Tweed, and R. J. Wilkins, 2003b. Comparison of grass and legume silages for milk production. 1. Production responses with different levels of concentrate. J. Dairy Sci. 86:2598-2611.

Dewhurst, R. J., K. J. Shingfield, M. R. F. Lee, and N. D. Scollan. 2006. Increasing the concentrations of beneficial polyunsaturated fatty acids in milk produced by dairy cows in high-forage systems. Anim. Feed Sci. Technol. 13:168-206.

Digman, M. F., K. J. Shinners, R. E. Muck, and B. S. Dien. 2010 Pilot-scale on-farm pretreatment of perennial grasses with dilute acid and alkali for fuel ethanol production. Trans. ASABE $53: 1007-1014$

Giallongo, F., M. T. Harper, J. Oh, C. Parys, I. Shinzato, and A. N. Hristov. 2017. Histidine deficiency has a negative effect on lactational performance of dairy cows. J. Dairy Sci. 100:2784-2800.

Gidlund, H., M. Hetta, and P. Huhtanen. 2017. Milk production and methane emissions from dairy cows fed a low or high proportion of red clover silage and an incremental level of rapeseed expeller. Livest. Sci. 197:73-81.

Gietzen, D. W., and Q. R. Rogers. 2006. Nutritional homeostasis and indispensable amino acid sensing: A new solution to an old puzzle. Trends Neurosci. 29:91-99.

Halmemies-Beauchet-Filleau, A., A. Vanhatalo, V. Toivonen, T. Heikkilä, M. R. F. Lee, and K. J. Shingfield. 2014. Effect of replacing grass silage with red clover silage on nutrient digestion, nitrogen metabolism, and milk fat composition in lactating cows fed diets containing a 60:40 forage-to-concentrate ratio. J. Dairy Sci. 97:3761-3776

Higgs, R. J., L. E. Chase, D. A. Ross, and M. E. Van Amburgh. 2015 Updating the Cornell Net Carbohydrate and Protein System feed library and analyzing model sensitivity to feed inputs. J. Dairy Sci. 98:6340-6360.

Hintz, R. W., D. R. Mertens, and K. A. Albrecht. 1996. Effects of sodium sulfite on recovery and composition of detergent fiber and lignin. J. AOAC Int. 79:16-22.

Hoffman, P. C., D. K. Combs, N. M. Brehm, and D. A. Welch. 1997. Performance of lactating dairy cows fed red clover or alfalfa silage. J. Dairy Sci. 80:3308-3315.

Hoffman, P. C., S. J. Sievert, R. D. Shaver, D. A. Welch, and D. K. Combs. 1993. In situ dry matter, protein, and fiber degradation of perennial forages. J. Dairy Sci. 76:2632-2643.

Hristov, A., and G. A. Broderick. 1994. In vitro determination of ruminal protein degradability using $\left[{ }^{15} \mathrm{~N}\right]$ ammonia to correct for microbial nitrogen uptake. J. Anim. Sci. 72:1344-1354.
Huhtanen, P., and G. A. Broderick. 2016. Improving utilisation of forage protein in ruminant production by crop and feed management. Pages 340-349 in The Multiple Roles of Grassland in the European Bioeconomy: Proc. 26th General Meeting European Grassland Federation, Trondheim, Norway. M. Höglind, A. K. Bakken, K. A. Hovstad, E. Kallioniemi, H. Riley, H. Steinshamn, and L. Østrem, ed. Wageningen Academic Publishers, Wageningen, the Netherlands.

Huhtanen, P., M. Hetta, and C. Swensson. 2011. Evaluation of canola meal as a protein supplement for dairy cows: A review and a metaanalysis. Can. J. Anim. Sci. 91:529-543.

Huhtanen, P., K. Kaustell, and S. Jaakkola. 1994. The use of internal markers to predict total digestibility and duodenal flow of nutrients in cattle given six different diets. Anim. Feed Sci. Technol. $48: 211-227$.

Huhtanen, P., M. Rinne, and J. Nousiainen. 2007. Evaluation of the factors affecting silage intake of dairy cows: A revision of the relative silage dry-matter intake index. Animal 1:758-770.

Jones, B. A., R. D. Hatfield, and R. E. Muck. 1995a. Characterization of proteolysis in alfalfa and red-clover. Crop Sci. 35:537-541.

Jones, B. A., R. D. Hatfield, and R. E. Muck. 1995b. Screening legume forages for soluble phenols, polyphenol oxidase and extract browning. J. Sci. Food Agric. 67:109-112.

Jones, B. A., R. D. Hatfield, and R. E. Muck. 1995c. Red-clover extracts inhibit legume proteolysis. J. Sci. Food Agric. 67:329-333.

Jung, H. G., D. R. Mertens, and R. L. Phillips. 2011. Effect of reduced ferulate-mediated lignin/arabinoxylan cross-linking in corn silage on feed intake, digestibility, and milk production. J. Dairy Sci. 94:5124-5137.

Krause, K. M., and D. K. Combs. 2003. Effects of forage particle size, forage source, and grain fermentability on performance and ruminal $\mathrm{pH}$ in midlactation cows. J. Dairy Sci. 86:1382-1397.

Lee, C., A. N. Hristov, T. W. Cassidy, K. S. Heyler, H. Lapierre, G. A. Varga, M. J. de Veth, R. A. Patton, and C. Parys. 2012. Rumenprotected lysine, methionine, and histidine increase milk protein yield in dairy cows fed a metabolizable protein-deficient diet. J. Dairy Sci. 95:6042-6056.

Lee, M. R. F., V. J. Theobald, J. K. S. Tweed, A. L. Winters, and N. D. Scollan. 2009. Effect of feeding fresh or conditioned red clover on milk fatty acids and nitrogen utilization in lactating dairy cows. J. Dairy Sci. 92:1136-1147.

Lee, M. R. F., A. L. Winters, N. Scollan, R. J. Dewhurst, M. K. Theodorou, and F. R. Minchin. 2004. Plant-mediated lipolysis and proteolysis in red clover with different polyphenol oxidase activities. J. Sci. Food Agric. 84:1639-1645.

Licitra, G., T. M. Hernandez, and P. J. Van Soest. 1996. Standardization of procedures for nitrogen fractionation of ruminant feeds. Anim. Feed Sci. Technol. 57:347-358.

McDonald, P., A. R. Henderson, and S. J. E. Heron. 1991. The Biochemistry of Silage. Chalcombe Publications, Marlow, UK.

Moorby, J. M., M. R. F. Lee, D. R. Davies, E. J. Kim, G. R. Nute, N. M. Ellis, and N. D. Scollan. 2009. Assessment of dietary ratios of red clover and grass silages on milk production and milk quality in dairy cows. J. Dairy Sci. 92:1148-1160.

Muck, R. E. 1987. Dry matter level effects on alfalfa silage quality. 1. Nitrogen transformations. Trans. Am. Soc. Agric. 30:7-14.

Nagel, S. A., and G. A. Broderick. 1992. Effect of formic acid or formaldehyde treatment of alfalfa silage on nutrient utilization by dairy cows. J. Dairy Sci. 75:140-154.

National Research Council. 2001. Nutrient Requirements of Dairy Cattle. 7th rev. ed. Natl. Acad. Sci., Washington, DC.

Nousiainen, J., K. J. Shingfield, and P. Huhtanen. 2004. Evaluation of milk urea nitrogen as a diagnostic of protein feeding. J. Dairy Sci. 87:386-398.

Oddy, V. H., and R. D. Sainz. 2002. Nutrition for sheep-meat production. Pages 237-262 in Sheep Nutrition. M. Freer and H. Dove, ed. CABI and CSIRO, Wallingford, UK.

Ouellet, D. R., and J. Chiquette. 2016. Effect of dietary metabolizable protein level and live yeasts on ruminal fermentation and nitrogen 
utilization in lactating dairy cows on a high red clover silage diet. Anim. Feed Sci. Technol. 220:73-85.

Papadopoulos, Y. A., and B. D. McKersie. 1983. A comparison of protein-degradation during wilting and ensiling of 6 forage species. Can. J. Plant Sci. 63:903-912.

Patton, R. A. 2010. Effect of rumen-protected methionine on feed intake, milk production, true milk protein concentration, and true milk protein yield, and the factors that influence these effects: A meta-analysis. J. Dairy Sci. 93:2105-2118.

Prigent, S. V. E., A. G. J. Voragen, F. Li, A. J. W. G. Visser, G. A. van Koningsveld, and H. Gruppen. 2008. Covalent interactions between amino acid side chains and oxidation products of caffeoylquinic acid (chlorogenic acid). J. Sci. Food Agric. 88:17481754.

Purwin, C., M. Fijałkowska, K. Lipiński, J. Wierzbowska, T. Z. Kobzhassarov, and J. Michalski. 2015. Changes in amino acid composition during ensiling lucerne and red clover in round bales. J. Elem. 20:965-973.

Roth, M. 1971. Fluorescence reaction of amino acids. Anal. Chem. $43: 880-882$

Russell, J. B., J. D. O'Connor, D. G. Fox, P. J. Van Soest, and C. J. Sniffen. 1992. A net carbohydrate and protein system for evaluating cattle diets: I. Ruminal fermentation. J. Anim. Sci. 70:35513561.

Santos, F. A. P., J. E. P. Santos, C. B. Theurer, and J. T. Huber. 1998. Effects of rumen-undegradable protein on dairy cow performance: A 12-year literature review. J. Dairy Sci. 81:3182-3213.

SAS Institute. 2013. 9.4: Guide to software updates. SAS Institute Inc., Cary, NC.

Satter, L. D., and L. L. Slyter. 1974. Effect of ammonia concentration on rumen microbial protein production in vitro. Br. J. Nutr. 32:199-208.

Socha, M. T., C. G. Schwab, D. E. Putnam, N. L. Whitehouse, B. D. Garthwaite, and G. A. Ducharme. 2008. Extent of methionine limitation in peak-, early-, and mid-lactation dairy cows. J. Dairy Sci. 91:1996-2010.

Steinshamn, H. 2010. Effect of forage legumes on feed intake, milk production and milk quality-A review. Anim. Sci. Pap. Rep. 28:195-206.
Sullivan, M. L., and R. D. Hatfield. 2006. Polyphenol oxidase and odiphenols inhibit postharvest proteolysis in red clover and alfalfa. Crop Sci. 46:662-670.

Valadares, R. F. D., G. A. Broderick, S. C. Valadares, and M. K. Clayton. 1999. Effect of replacing alfalfa silage with high moisture corn on ruminal protein synthesis estimated from excretion of total purine derivatives. J. Dairy Sci. 82:2686-2696.

Van Amburgh, M. E., E. A. Collao-Saenz, R. J. Higgs, D. A. Ross, E. B. Recktenwald, E. Raffrenato, L. E. Chase, T. R. Overton, J. K. Mills, and A. Foskolos. 2015. The Cornell Net Carbohydrate and Protein System: Updates to the model and evaluation of version 6.5. J. Dairy Sci. 98:6361-6380.

Van Soest, P. J. 1994. Nutritional Ecology of the Ruminant. 2nd ed. O \& B Books, Corvallis, OR.

Van Soest, P. J., J. B. Robertson, and B. A. Lewis. 1991. Methods for dietary fiber, neutral detergent fiber, and nonstarch polysaccharides in relation to animal nutrition. J. Dairy Sci. 74:3583-3597.

Vanhatalo, A., K. Kuoppala, S. Ahvenjärvi, and M. Rinne. 2009. Effects of feeding grass or red clover silage cut at two maturity stages in dairy cows. 1. Nitrogen metabolism and supply of amino acids. J. Dairy Sci. 92:5620-5633.

Zanton, G. I. 2016. Analysis of production responses to changing crude protein levels in lactating dairy cow diets when evaluated in continuous or change-over experimental designs. J. Dairy Sci 99:4398-4410.

Zanton, G. I., G. R. Bowman, M. Vázquez-Añón, and L. M. Rode. 2014. Meta-analysis of lactation performance in dairy cows receiving supplemental dietary methionine sources or postruminal infusion of methionine. J. Dairy Sci. 97:7085-7101.

Zhou, Z., M. Vailati-Riboni, N. D. Luchini, and J. J. Loor. 2016. Methionine and choline supply during the periparturient period alter plasma amino acid and one-carbon metabolism profiles to various extents: Potential role in hepatic metabolism and antioxidant status. Nutrients 9:10. 